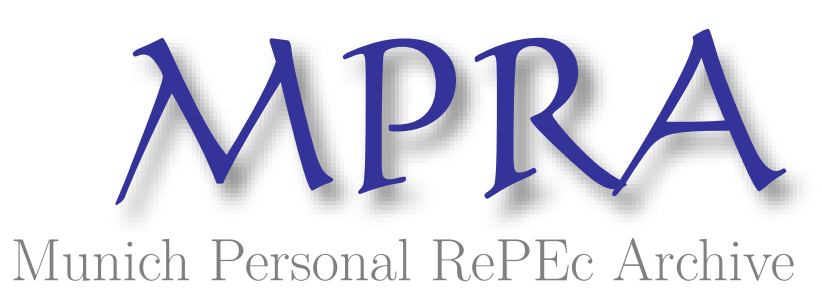

\title{
Cross-border Acquisitions in a Transition Economy: Recent Experiences of China and India
}

\author{
Nagano, Mamoru \\ Nagoya City University
}

2007

Online at https://mpra.ub.uni-muenchen.de/24568/

MPRA Paper No. 24568, posted 22 Aug 2010 23:44 UTC 


\title{
Cross-border Acquisitions in a Transition Economy: Recent
}

\author{
Experiences of China and India
}

\author{
Mamoru Nagano ${ }^{\dagger}$ Yuan Yuan $\ddagger$
}

\begin{abstract}
This paper examines the causes and consequences of cross-border acquisitions in a transition economy using the 1998-2006 deal data for targeted Chinese and Indian firms and foreign acquirers. Our empirical analysis resulted in three important findings. First, firms with high cash reserve ratio are likely to be targeted in the recent cross-border acquisition trends in China and India; remarkably so when the cash-rich target has a high growth opportunity. Second, cross-border acquisitions bring higher shareholders' values for foreign acquirers than for domestic acquirers. Third, these empirical results differ from existing literature where acquirer's shareholder's return is low in general.
\end{abstract}

\section{JEL Classification: O21, O25, G34}

Keywords: Transition economy, Mergers and acquisition

\section{Introduction}

There is a vast literature on corporate acquisitions including several empirical studies on the causes and consequences of mergers. Some suggested technological innovations, industrial deregulations and changes in demographic structures as the major causes. Others reported that acquisitions brought about both positive and negative impacts in the post-acquisition period. Most of the literature used datasets of U.S. firms, but the number of studies using data from other countries has recently increased as merger waves hit other countries around the world. Clearly, there is an increasing merger wave hitting not only the industrialized countries, but also emerging countries as the latter promote economic transition by releasing

\footnotetext{
$\dagger$ Corresponding author, Professor, Nagoya City University, Yamanohata 1, Mizuho, Nagoya 467-8501 Japan, Tel/Fax : +81-52-872-5736, Email: mnagano@econ.nagoya-cu.ac.jp

‡ Project assistant professor, The University of Tokyo, 7-3-1,Hongo, Bunkyo-ku, Tokyo 113-8656 Japan, Email: yuan_yuan@tmi.t.utokyo.ac.jp
} 
state-owned shares.

In East Asia, the number of acquisitions by foreign firms dramatically increased after the 1997/98 financial crisis. One of the causes cited was the enhanced purchasing power of foreign acquirers following the currency devaluation and falling stock prices in the region. Other triggers mentioned included the widespread privatization of state-owned enterprises and deregulation of capital transactions. Ten years after the crisis, however, the number of corporate acquisitions has been increasing still, especially in emerging countries. Remarkably, transition economies that did not experience currency crisis recorded even larger number of mergers and acquisitions (M\&As). One possible reason for this dramatic increase is that foreign firms have become more aggressive purchasers of the released shares of state-owned enterprises, at the same time that governments in transition economies have been promoting inward investments by deregulating the existing legislations.

According to United Nations Conference on Trade and Development, total international direct investment exceeded US\$ 1,300 billion in 2006 with a significant increase contributed by the emerging countries. In fact, cross-border corporate acquisitions accounted for sixty seven percent of international direct investment flow in the same year. The Chinese Eleventh Five-year plan of 2006 explains how the government regards the recent acquisition trend and the purpose of inward investment promotion policy. Specifically, the government expects cross-border acquisition to bring with it advanced technology, stronger managerial discipline, and wider international delivery channels in addition to large equity funds. Against this background, merger waves can be expected to hit both industrialized and emerging countries more frequently, resulting in higher international direct investments. For emerging transition economies, governments are more likely to pursue M\&As to activate stagnating firms.

More recent literature using U.S. sample firms pointed out three factors that contribute to corporate value maximization from acquisitions. First, an acquisition enables the acquirer to obtain new technology and higher productivity ${ }^{1}$. Second, the acquirer expects the corporate acquisition to improve the managerial discipline of the targeted firm as noted by Morck et al.(1998) and Lang et.al.(1989). Third, shareholders' potential rights to eliminate nonperforming managers contribute to an increase in corporate value regardless of the elimination by acquisition. This is also suggested by the above literatures. Chari et al. (2008) use cross-country data to investigate shareholder value gains from target acquisition, and find that acquiring a control over a target can bring high abnormal returns, especially for firms from the

\footnotetext{
1 Andrade et.al.(2001) and Mitchell and Mulherin(1996) pointed out that merger wave hits a limited number of industries during a short-term period. But, when the industrial sectors experienced technological innovation, deregulation and other factors that contribute to a dramatic change in industry productivity, a merger wave likely follows.
} 
developed countries. However, there is only sparse literature on M\&As focusing on transition economies such as China and India.

It is possible that the Chinese and the Indian governments promoted corporate acquisition because of its potential benefits, e.g, synergy effect and managerial discipline, on the privatized state-owned firms. In the case of cross-border acquisitions, the expected return from a transfer of new technology, management know-how, and more international delivery channels seem to be attractive enough to increase the productivity of quasi state-owned firms in China and India. Therefore, since the existing literature cannot be used to fully explain the recent acquisition trend in transition economies, we believe that studies focusing on the transition economies are quite valuable. In this paper, we analyze the effects of M\&As on the process of economic development in China and India.

This paper will examine three propositions. The first is to verify common characteristics of target firms that foreign acquirers prefer. We will empirically test the factors that influence the foreign acquirer's investment decision by looking at characteristics of targets. The second is to find out how the capital market evaluates the announcement of cross-border acquisition. In particular, the types of cross-border acquisition that bring larger shareholder's value will be examined. The third is to verify and evaluate universal common characteristics of foreign acquirers that bring larger shareholder's value for both acquirers and targets. By using acquisition deal data matched with firms' financial statements, this paper will identify the causes and consequences of cross-border acquisitions in China and India.

\section{Testing Hypotheses and the Data}

Table 1 suggests that the number of acquisitions in China and India dramatically increased since 2002. In China, the number grew from 64 in 2001 to 227 in 2006. There was also a remarkable increase in the number of deals for the targeted unlisted firms in both countries. In India, the ratio of publicly listed targets was high until 1999, but it dramatically decreased since 2002. Foreign acquirers, meanwhile, contributed to the higher number of unlisted targets in China and India with unlisted firms targeted by foreign acquirers for both countries at more than thirty percent of total deals.

\section{Table 1 about here}

In terms of targeted industrial group, Table 2 shows a large number of targeted firms in real estate business and construction, reflecting the recent domestic construction boom in Chinese and Indian metropolitan areas. The number of firms in telecommunications is also large in China which can be attributed to the recent 
progress of deregulation in this sector since China joined WTO in 2001. The number in financial services is also large in China and in the pharmaceutical industry in India. These data point to the common trend of an increasing number in targeted firms in the recently deregulated industrial groups. However, country specific factors also exist as shown in Chinese financial business and Indian pharmaceutical industry.

Unlike Chari et al. (2008), who examine the consequences of acquisitions especially for firms from the developed countries, we employ three approaches to examine not only the consequences but also the factors encouraging cross-border acquisitions in China and India, in order to analyze the effects of M\&As on economic development in transition economies. The first approach examines if determinants of targets influencing an acquirer's decision differ between cross-border and domestic deals. The second approach verifies cumulative abnormal returns of cross-border and domestic deals and compare them by using event study. This approach adopts the methodology of Brown and Warners (1985) by statistically examining the differences between cross-border and domestic deals. The third approach examines what type of acquirers bring about high abnormal returns for both cross-border and domestic deals.

The empirical data were obtained from Bloomberg's "M\&A League Table". The dataset covered all the announced data of the world including deals with low percentage of stock holding ratio and even those in emerging countries. We also used sample data of deals announced from January 1, 1998 - December 31, 2006. Sample targeted firms refer to both listed and unlisted firms in China and India. We extracted announced deals with more than fifty percent of targeted stock holding ratio, lowering the ratio to 10 percent in analyzing targets' characteristics. Differing from existing studies focusing on target firms in the industrialized countries, we did not set any lower bound for the total amount of deal value. The acquirers refer to all foreign and domestic listed firms to compare these two empirical results, except firms in the financial sector and utilities. We also excluded in the sample those acquirers with more than two deals within five business operating days because it is difficult to specify which deal influenced an increase in the acquirer's stock price. Information on type of payment in China and India are not covered by Bloomberg's database and difficult to obtain from any other databases, and are also excluded in this study².

\footnotetext{
2 In China, "Provisional Rule of Corporate Acquisition by Foreigners" came into effect in April 2003. It is generally viewed that the Chinese government has encouraged foreign institutional investors to acquire a firm in China since then. This rule was adopted as a joint amendment by The Ministry of Commerce, State Administration of Foreign Exchange and The China Securities Regulatory Commissions in September 2006 as "A Rule for Foreign Investors to Acquire Chinese Firm". The rule contains the detailed regulations and allows foreign acquirers to employ stock as a method of payment.
} 
Table 2. about here

\section{What types of targets attract foreigners?}

This section addresses the characteristics of targets that influence the investment decisions of foreign and domestic acquirers. There are several studies that focused on this issue. By examining the free-cash flow problem and using it as a proxy for non-working internal control mechanisms of the firm, Hartford (2005) suggested that cash-rich firms are likely to be targeted. Hanson (1992) and Smith and Kim (1994) pointed out another hypothesis that firms with good investment opportunities and less financial resources have an incentive to acquire cash-rich firms. Taking another approach, they've also concluded that cash-rich firms are likely to be targeted. Hasbrouck (1985), however, has shown that firms with high growth opportunities are less likely to be targeted because such firms do not need any external intervention. Existing literature generally focus on the relationship between characteristics of targets and efficiency of internal management mechanisms as suggested also by Lang et al. (1991), Servaes (1991) and Mork et al.(1988). Our study also employs the same variables since firms in a transition economy need more external intervention.

Our study uses the acquisition's deal and financial data of the listed targets in China and India from 1999 to 2006, and extracts deals with more than 10 percent targeting share of stock acquisition. Reflecting the above literature together with the Chinese and Indian country specific backgrounds, our first hypothesis is that the volume of internal cash reserve influences an investment decision of acquirer for both China and India. This is because there is stronger incentive for external intervention in the internal corporate mechanism of cash-rich quasi state-owned firms under a share releasing plan by the government. Our second hypothesis is that firms with high growth opportunities are likely to be targeted, contrary to the findings of existing literature. We consider foreign acquirers to have much larger purchasing power and incentives to maximize returns when the target firms show good growth opportunities.

Our empirical model as shown in equations (1.1) and (1.2) employs announced targeted stock holding ratio as a dependent variable when the firm is the target of an acquisition attempt and others are 0 in year $t$. The independent variables are the three-year averaged financial data. Therefore, the dependent variables are virtually the announced deals in 2001-2006. When a firm turns out as a target by the announcement in year $t$, the firm is eliminated from the sample in the following year. Six industrial dummy, five year dummy and five regional dummy variables are added to the equations. 


$$
\begin{aligned}
& S H R_{i t}^{1}=\text { const }+\alpha_{1} S I Z E_{i t-1}+\alpha_{2} D_{E R} R_{i t-1}+\alpha_{3} C A S H_{i t-1} \\
& +\alpha_{4} \text { FIXED }_{i t-1}+\alpha_{5} \text { MBR }_{i t-1}+\alpha_{5} \text { Cash }_{-} Q_{i t-1}+v_{i t} \\
& S H R_{i t}^{2}=\text { const }^{\prime}+\beta_{1} \operatorname{SIZE}_{i t-1}+\beta_{2} D E R_{i t-1}+\beta_{3} C A S H_{i t-1} \\
& +\beta_{4} \text { FIXED }_{i t-1}+\beta_{5} M_{B} R_{i t-1}+\beta_{5} \text { Cash_ } Q_{i t-1}+v_{i t}{ }^{\prime}
\end{aligned}
$$

$S H R^{1}$ : announced targeted stock holding ratio by foreign acquirer in year $t$, " $=0$ " when the firm is not the target of cross-border acquisition attempt in year $t, \mathrm{SHR}^{2}$ : announced targeted stock holding ratio by domestic acquirer in year $\mathrm{t}, "=0$ " when the firm is not the target of domestic acquisition attempt in year $\mathrm{t}$, SIZE: Natural logarithm of book valued total assets, DER: Book valued total liability/market valued capital, CASH: Book valued cash reserves/ Book valued total assets, FIXED: Book valued fixed assets/Book valued total assets, ROA: Return on assets, , MBR: (Book valued total liability + Market valued capital )/ Book valued total assets

Our empirical analysis showed that for cross-border acquisitions, parameters of cash reserve ratio and the intersection between cash reserve and market to book ratio are significantly positive in China, while cash reserve ratio and the intersection variable are also both positively significant for Indian firms. These results confirm our first hypothesis that firms with ample cash are likely to be targeted by foreign acquirers in China and India. This variable is used as a proxy if there is a room for improvement in the management of firms. Therefore, our empirical results suggest that the cash rich Chinese and Indian firms would need acquirers' intervention for them to operate efficiently.

For acquisitions between domestic acquirers and targets in China, parameters of firm size and book-to-market ratio are significant with the firm size negative and that of book-to-market ratio positive. In India, parameters of firm size, cash reserve ratio and intersection variable between cash reserve ratio and book-to-market ratio are positively significant.

On the other hand, it is difficult to confirm our second hypothesis. Parameters of market to book ratio in the case of cross-border acquisitions turned out insignificant for both China and India. However, parameters of intersection variable between cash reserve and book-to-market ratio are both significantly positive. This suggests that a firm with high growth opportunities is attractive only when the firm has ample cash reserves. The parameter firm size is negatively significant for Chinese acquisitions. Mikkelson and Partch (1989) and Song and Walkling (1993) also reported that size negatively relates to target incidence. Our study found a similar trend in this variable. Parameters of several industrial dummy variables are significant. These suggest that industrial effects are also important factors in the acquirers' decision making. 


\section{Table 3. about here}

\section{Do cross-border acquisitions increase shareholder's value?}

This section aims to verify the consequences resulting from the recent acquisitions in China and India. Focusing on shareholders' gains from acquisitions, we examined if acquisitions contributed to an increase in shareholders' values in transition economies. Using the event study methodology, we considered stock price as reflecting the future result of the acquisition. In other words, stock price right after the announcement reflects expected economic value added obtained by acquisitions. A standard event study methodology was adopted to calculate abnormal returns originally developed by Brown and Warner (1985). The abnormal returns over three-day event window $(-1,1)$ around the announcement date using market model benchmark returns were estimated and market benchmark indexes were respectively extracted from the mother country market of each acquirer. Some 40 one-day event studies $(-20,20)$ were added to the above three-day event study. By calculating abnormal returns of short-term and long-term period, we discussed the sources and origins of the differences. The parameters for the market model were estimated over the $(-256,-21)$ interval.

Using the above cumulative abnormal returns, this paper investigates three hypotheses. The first hypothesis is that foreign acquirers, i.e., cross-border acquisitions, brought larger shareholders' value than domestic acquirers. This hypothesis comes from the observation that foreign shareholders of the industrialized countries enhance the monitoring of corporate managers resulting in managerial discipline. Jensen $(1986,1988)$, Shleifer and Vishny $(1986,1998)$ emphasized the importance of shareholder's monitoring citing as an example the improvement in managerial discipline resulting from concentrated ownership structure. Chari et al. (2008) show that the return to an acquirer gaining control of a target in a developed country is significantly increased. In this paper, following the previous studies mentioned above, we assume that acquisition by a foreign acquirer leads to enhancement of monitoring in addition to obtaining international distribution channels, new technology and other sources of high productivity. This approach is close to the conclusion of Anderade et al. (2001), Hasbrouck (1985), Servaes (1991) and Lang et al. (1989) that pointed out that targeted firms are generally low growth opportunity firms and acquirers are able to improve the target firm's managerial discipline. ${ }^{3}$

3 There are several literature suggesting growth opportunity is not an appropriate proxy variable for a change in managerial discipline. Differing from Rau and Vermaelen (1998) and Shleifer and Vishny (2003), it is our stand that the variable represents managerial discipline as pointed out in Andrade et al. 
Our second hypothesis is that the shareholders of an acquirer receive larger returns when the target is a publicly unlisted firm. This hypothesis is also based on existing literature in the United States. For example, Chang (1998) and Hansen and Lott (1996) examined returns from private acquisition targets. The former suggested that unlisted firms have less concentrated ownership structure, hence, monitoring management of the target firm does not always work. Hansen and Lott (1996) pointed out the same view, but from another hypothesis. Their contention is that acquisition of a public firm sometimes result in discounted shareholder value for the acquirer, and the total value of the two firms are not maximized. However, when the target is a private firm, the acquisition leads to maximization of shareholder's portfolio, once the target went IPO in the future. While Fuller et al. (2002) and other literature questioned the above conclusions, our analysis assumes that, in a transition economy, acquisition of private firms also leads to effective monitoring.

The third hypothesis on vertical acquisition, i.e., industrial sectors of acquirers and targets are close, improves productivity in the industry and brings higher shareholder's value. In the United States, Berger and Ofek (1995) reported that stock price of a diversified firm is undervalued because investors regard that the firm misallocate the corporate resources and inefficiency exists inside. Morck et al. (1990) and Bhagat et al. (2005) also reported that stock price of the firm is higher when the industrial sectors of acquirer and target are close. Although some literature such as Agrawal et al. (1992) and Sirower (1997) reported that stock price of the horizontal acquisition brought higher stock price in their empirical results, we assume vertical acquisition brings better efficiency in resource allocation between acquirer and target.

This section examines a sample using several criteria. The first criterion refers to deals between both listed and private targets and publicly listed acquirers announced from 1 January 1998 to 31 December 2006. Deals with more than 50\% announced acquisitions and completed as of December 31, 2007 are extracted from the sample. Banks, securities firms, insurance firms and other financial firms are excluded as an acquirer from the sample. Other deals that the same acquirer announced in five operating days are also excluded.

Table 4 shows the three-day and forty one-day cumulative abnormal returns classified by type of deals. In table 4.A, cumulative abnormal return is significantly positive in China. However, when we differentiate the returns on the basis of whether the acquirer is a foreign firm or Chinese firm, we find that the return is significantly positive for foreign acquirers. As for the cumulative abnormal returns on the basis of whether the target is a publicly listed firm or not in cross-border deals, we find that the return is significantly higher when the target is unlisted firm. The cumulative abnormal return is also significantly high when the foreign acquirer and 
domestic target belong to the same industry. To summarize, the above empirical results suggest that a foreign acquirer belonging to the same industrial group as an unlisted target provides the most significant positive additional shareholder's value in China.

Table 4.B shows the empirical results of acquisitions in India. The results of the tests for all samples suggest that cumulative abnormal return of acquirer's shareholder is significantly positive in India as a whole. The returns of both cross-border and domestic acquisitions are also significantly positive, but the cross-border acquisition is significantly higher than the domestic. In testing for the difference of cumulative abnormal returns between the listed and unlisted target, we find that the returns are significantly higher when the target is unlisted in case of cross-border acquisition. In India, empirical results suggest that the cumulative abnormal return of own-industry acquisition is significantly higher in case of cross-border acquisitions as well. The above results suggest that cross-border acquisition also brings more significant additional shareholder's value in India and the returns are higher when the target is an unlisted firm and belongs to the same industrial group.

\section{Table 4. about here}

\section{Who is a good acquirer?}

The third empirical analysis focuses on types of acquirers that bring high cumulative abnormal returns. Existing literature on this issue relates to those mentioned in the previous section. Lang et al. (1989) pointed out that acquirers with high book-to-market ratio resulted in high cumulative abnormal returns in an 11-day event around the announcement. This is because the acquirer with high book-to-market ratio is expected to bring better efficiency in management for the target. Servaes (1991) supported the above view suggesting that the target has a room for efficiency improvement from an acquirer with high book-to-market ratio. In this study, we assume that an acquirer with high book-to-market ratio also improves the managerial discipline of firms in China and India. Moeller et al. (2004), Dong et al. (2002) and Malmendier and Tate (2002) pointed out that an acquirer's firm size is important in determining shareholder's return based on their review of U.S. acquisitions. We do agree that a small acquirer obtains relatively larger synergy effect than large firms and we use the same hypothesis in this paper.

Four datasets are prepared to examine the types of acquirers, namely, two datasets on CARs, financial data of acquirers and targets for cross-border deals in China, and two others on CARs, financial data of acquirers and targets for 
cross-border deals in India. The sample period covers 2000 to 2005. The criterion used to extract sample deal data of the acquisition is the same as in sections III and IV.

In completing the dataset, we first matched a firm's individual CAR data, financial data of acquirer and those of target. Here we employed $(-1,1)$ CAR data. Next, we extracted firms that belong to the same industrial category of a target on every deal. We regard these firms as potential targets, but not offered by acquirers. We matched financial data of these potential targets and those of acquirers that actually made deals with real targets on every deal. In this case, CAR is " 0 " since they are not targeted after all by either foreign or domestic acquirer. The above targeted data and potential targeted data are merged and we estimated the below empirical equations with these merged data by using Tobit estimation.

$$
\begin{aligned}
& C A R_{i}^{1}=\text { const }+\chi_{1} R_{S I Z E_{i}}+\chi_{2} M B R_{-} A_{i}+\chi_{3} \frac{M B R_{-} A_{i}}{M B R_{-} T_{i}} \\
& +\chi_{4} M B R_{-} A^{*} C A S H_{-} T_{i}+\chi_{5} \text { Ownership }_{i}+\imath_{i}^{1} \\
& C A R_{i}^{2}=\text { const }+\delta_{1} R_{S I Z E_{i}}+\delta_{2} M B R_{-} A_{i}+\delta_{3} \frac{M B R_{-} A_{i}}{M B R_{-} T_{i}} \\
& +\delta_{4} M B R_{-} A^{*} C A S H_{-} T_{i}+\delta_{5} \text { Ownership }_{i}+l_{i}{ }^{2}
\end{aligned}
$$

$\mathrm{CAR}^{1}$ : Cumulative abnormal return of foreign acquirer $(-1,1), \mathrm{CAR}^{2}$ : Cumulative abnormal return of domestic target $(-1,1)$, RSIZE: natural logarithm of total assets of acquirer divided by that of target in terms of US dollar, MBR_A: Book value of total liability plus market value of capital divided by total assets for acquirer, MBR_T: Book value of total liability plus market value of capital divided by total assets for target, CASH_T: Cash reserve divided by total assets of target, Ownership: Targeted stock holding ratio announced.

Our empirical results suggest that parameters of relative firm size, intersection variable between acquirer's book-to-market ratio and target's cash reserve and ownership are significant when dependent variable is foreign acquirer's cumulative abnormal return in China. Here, the sign of the parameters of the intersected variable and ownership is positive and that of relative firm size is negative. This means that an acquirer's cumulative abnormal return is statistically high when the acquirer has a high book-to-market ratio and the target has an ample cash reserve. However, acquirer's shareholder's value is low when the acquirer is a large firm compared with the target. This contrasts with our hypothesis. In our study, the parameter of relative firm size is insignificant when a target's cumulative abnormal return is the dependent variable. In India, the parameter of intersection variable between acquirer's book-to-market ratio and target's cash reserve is significantly positive. This suggests that the acquirer's shareholder's value increases when the deal is made by an acquirer with high book-to-market ratio and the target has an ample cash reserve. A target's shareholder's value is also high when the deal is made by an 
acquirer with high book-to-market ratio and the target has ample cash reserve.

\section{Table 5. about here}

\section{What does the recent cross-border acquisition wave eventually brings?}

In summary, our empirical results support the three hypotheses of this paper, namely: (i) cash-rich firms are targeted in China and India as is generally done in the industrialized countries; (ii) cross-border acquisition statistically records higher cumulative abnormal returns than domestic acquisition; and (iii) the shareholder's value for acquirer is larger when the foreign acquirer purchases publicly unlisted targets. However, one hypotheses is not supported, i.e., the relative size of an acquirer and target does not always affect the shareholder's value in the case of Chinese and Indian deals.

Our empirical study used cash reserves to total assets (CASH_T) as a proxy of firm's internal fund. This variable implies that when the ratio is high, the target has a room to improve the managerial discipline and the productivity as a result of acquisition. The improved managerial discipline leads to a more efficient fixed asset or R\&D investment by using the target's internal cash. As confirmed in several literature, the variable CASH_T significantly influences an acquirer's decision. This empirical result is very remarkable in China and India because both countries experienced approximately 10 percent economic growth, and state-owned firms also recorded high growth rate of corporate cash inflow in recent years. In the midst of market oriented economic reforms, a large number of firms had ample internal funds and more rooms for reforms. Therefore, the government's recent pronouncement promoting acquisition is most likely to contribute to an improvement in overall economic efficiency. Our empirical results suggest that not only foreign investors, but domestic investors as well contributed to the improvement in cost efficiency in the industrial organizations of China and India.

The second empirical analysis also supports the government's recent promotion of inward investment policy. Contrary to acquisitions in the industrialized countries, there are still plenty of restrictions in purchasing and holding equity of listed firms by foreigners in China and India. In addition, in both countries, government still holds majority of publicly listed shares. This study suggests that future deregulation of equity transaction by foreigners in a capital market will contribute to an improvement in industrial organization and enlarge the shareholder's value. On the other hand, the results also suggest that it would be difficult to improve the productivity of listed firms as long as governments remain the largest shareholders. 
The third empirical analysis suggests that for Chinese and Indian targets, foreign firms with high growth opportunity are good acquirers. This result has several implications. An acquisition by a firm with high growth opportunity implies that management of the targeted firm is influenced by managers of acquirers. Since an acquiring firm with high growth opportunity generally has better managerial discipline than the target, the acquisition can also contribute to an improvement of inefficient management in China and India.

In the late 1990s, the dramatic increase in short-term investment in emerging countries triggered the financial crisis. Based on an analysis of the firm's micro deal data, however, our study reveals that the recent dramatic increase in cross-border acquisitions in transition economies does not worsen economic efficiency, but strongly helps transition and promotion of market oriented economy.

\section{Concluding Remarks}

Focusing on China and India, this paper examined the causes and consequences of acquisitions in a transition economy. We found evidence that cashrich firms were targeted more frequently as similarly observed in the industrialized countries. Our analysis also showed that cross-border acquisitions contributed to an increase in shareholder's value. Based on the assumption that an increase in shareholder's value soon after the deal announcement reflects expectations of future overall corporate value, our results confirmed that the recent increase in cross-border acquisition contributed to a future improvement in economic development as the two countries pursue market oriented economic reforms.

In 1990s, international capital inflows triggered several financial crises in emerging countries. Since these events arose, a short-term capital inflow has been regarded as possible financial distortion in these countries. However, our empirical study revealed that the recent trend of international capital flow, i.e., cross-border acquisition, provide an increase in shareholder's value for both acquirers and targets. Furthermore, cross-border acquisition is beneficial not only for firms in emerging countries, but also for investors in the industrialized countries. As pointed out in most literature, a shareholder's value for acquirers does not always increase for domestic deals in the industrialized countries.

This paper verified not only the causes of acquisitions, but also the consequences in a transition economy. Although our empirical analysis focused only on China and India, our findings have important implications on the other emerging transition countries around the world. Future studies need to examine if countries with high growth rate, large amount of natural resources and energy exhibit similar characteristics as we found in our study of China and India. These studies must reflect 
how future inward investment promotional policy by acquisitions could increase efficiency.

\section{References:}

Agrawal, A., J. F. Jaffe, and G. N. Mandelker (1992), “The post-merger performance of acquiring firms: A re-examination of an anomaly," Journal of Finance 47 (4), pp.1605-1621.

Andrade, G. and E. Stafford (1999) , "Investigating the economic role of mergers," Harvard University working paper.

Andrade, G., M. Mitchell, and E. Stafford (2001) , "New evidence and perspectives on mergers," Journal of Economic Perspectives 15(2), pp.103-120.

Berger, P. G. and E. Ofek (1995), "Diversification's effect on firm value," Journal of Financial Economics 37 (1), pp.39-65.

Bhagat, S., M. Dong, D. Hirshleifer, and R. Noah (2005), “Do tender offers create value? New methods and evidence," Journal of Financial Economics 76 (1), pp.61-98.

Bradley, M., A. Desai, and E. H. Kim (1988), "Synergistic gain from corporate acquisitions and their division between the stockholders of target and acquiring firms," Journal of Financial Economics 21(1) , pp.61-98.

Brown, S. J. and J. B. Warner, (1985), "Using daily stock returns: the case of event studies," Journal of Financial Economics 14, pp. 3-31.

Chari, A., P. P. Ouimet, and L. L. Tesar (2008), "The Value of Control in Emerging Markets," University of North Carolina working paper, available at http://www.unc.edu/ achari/control.pdf

Chang, S. (1998), "Takeovers of privately held targets, methods of payment, and bidder returns," Journal of Finance 53, pp.773-784.

Dong, M., D. Hirshleifer, S. Richardson and S. H. Teoh (2002), "Does investor misevaluation drive the takeover market?" Unpublished working paper, The Ohio State University, Columbus, $\mathrm{OH}$.

Fama, E., and K. French (1997), "Industry costs of equity," Journal of Financial Economics 43, pp.153-193.

Fuller, K., J. Netter, and M. Stegemoller (2002), "What do returns to acquiring firms tell us? Evidence from firms that make many acquisitions, The Journal of Finance VOL LVII, No.4, pp.1763-1793.

Hansen, R. G. and J. Lott, (1996), "Externalities and corporate objectives in a world with diversified shareholders/consumers," Journal of Financial and Quantitative Analysis 31, pp.43-68.

Hanson, R., (1992), "Tender offers and free cash flow: An empirical analysis," Financial Review 27, pp.185-209. 
Harford, J., (1999) , "Corporate Cash Reserves and Acquisitions," The Journal of Finance, JOL. LIV, NO6. December 1999. pp.1969-1997.

Harford, J. (2005), “What drives merger waves?” Journal of Financial Economics 77 (3), pp.529-560.

Hasbrouch, J. (1985), "The characteristic of takeover targets. Q and other measures," Journal of Banking and Finance 9 (3), pp.351-362.

Jensen, M. C., (1986), "Agency costs of free cash flow, corporate finance, and takeovers," American Economic Review 76 (2), pp.323-329.

Jensen, M. C., (1988), “Takeovers; Their causes and consequences," Journal of Economic Perspective 2 (1), pp.21-48.

Lang, L. H. P., R.M. Stulz, and R. Walking (1989) , “Managerial performance, Tobin's $\mathrm{Q}$ and the gains from successful tender offers," Journal of Financial Economics 24(1) , pp.137-154.

Malmendier, U. and G.A. Tate, (2002), "Who makes acquisitions?" CEO overconfidence and the market's reaction," Unpublished working paper, Harvard Business School, Cambridge, MA.

Mikkelson, W. and M. M. Partch, (1989), "Managers' voting rights and corporate control," Journal of Financial Economics 25, pp.263-290.

Moeller, S.B., F.P. Shlingemann, and R.M. Stulz (2004), "Firm size and the gains from acquisitions," Journal of Financial Economics 73, pp.201-228.

Mitchell, M. L. and J. H. Mulherin (1996), “The impact of industry shocks on takeover and restructuring activity," Journal of Financial Economics 41(2), pp. 193-229.

Morck, R., A. Shreifer, and R. W. Vishny (1988), "Alternative mechanism for corporate control," NBER Working Paper Series No. 2532, National Breau of Economic Research.

Morck, R., A. Shreifer, and R. W. Vishny (1990), "Do managerial motives drive bad acquisitions?" Journal of Finance 45 (1), pp.31-48.

Palepu, K. G. (1986), "Predicting takeover targets: A methodological and empirical analysis," Journal of Accounting and Economics 8 (1), pp.3-35.

Rau, P. R. and T. Vermaelen (1998), "Glamour, value and the post-acquisition performance of acquiring firms," Journal of Financial Economics 49 (2), pp. 223-253.

Servaes, H. (1991), “Tobin's Q and the gain from takeovers," Journal of Finance 46 (1), pp.409-419.

Shleifer, A. and R. W. Vishny (1986), "Large shareholders and corporate control," Journal of Political Economy 95 (June), pp.461-488.

Shleifer, A. and R. W. Vishny (1988), "A survey of corporate governance," Journal of Finance 52 (2), pp.737-783.

Shleifer, A. and R. W. Vishny (2003), "Stock market driven acquisitions," Journal of Financial Economics 70 (3), pp.295-311.

Sirower, M. L., (1997), The Synergy Trap: How Companies Lose the Acquisition Game, Free 
Press.

Smith, R. and J. H. Kim, (1994) "The combined effects of fee cash flow and financial slack on bidder and target stock returns," Journal of Business 67, pp.281-310.

Song, M. and R. Walking, (1993), “The impact of managerial ownership on acquisition attempts and target shareholder wealth," Journal of Financial and Quantitative Analysis 28, pp.439-457. 
Table 1. Number of M\&As in China and India

\begin{tabular}{rrrrrrrr}
\hline (a) China & Number of M\&A & \multicolumn{3}{c}{ Publicly Listed Targets } & \multicolumn{2}{c}{ Foreign Aquirers } & \multicolumn{2}{c}{ Own Industry M\&A } \\
\hline 1998 & 1 & 0 & $(0.0 \%)$ & 1 & $(100.0 \%)$ & 1 & $(100.0 \%)$ \\
1999 & 2 & 0 & $(0.0 \%)$ & 2 & $(100.0 \%)$ & 2 & $(100.0 \%)$ \\
2000 & 34 & 1 & $(2.9 \%)$ & 25 & $(73.5 \%)$ & 11 & $(32.4 \%)$ \\
2001 & 64 & 2 & $(3.1 \%)$ & 39 & $(60.9 \%)$ & 27 & $(42.2 \%)$ \\
2002 & 159 & 22 & $(13.8 \%)$ & 67 & $(42.1 \%)$ & 58 & $(36.5 \%)$ \\
2003 & 167 & 15 & $(9.0 \%)$ & 59 & $(35.3 \%)$ & 69 & $(41.3 \%)$ \\
2004 & 268 & 9 & $(3.4 \%)$ & 114 & $(42.5 \%)$ & 118 & $(44.0 \%)$ \\
2005 & 292 & 14 & $(4.8 \%)$ & 99 & $(33.9 \%)$ & 127 & $(43.5 \%)$ \\
2006 & 227 & 7 & $(3.1 \%)$ & 108 & $(47.6 \%)$ & 93 & $(41.0 \%)$ \\
\hline Total & 1,214 & 70 & $(5.8 \%)$ & 514 & $(42.3 \%)$ & 506 & $(41.7 \%)$ \\
\hline
\end{tabular}

\begin{tabular}{rrrrrrrr}
\hline (b) India & Number of M\&A & \multicolumn{3}{c}{ Publicly Listed Targets } & \multicolumn{2}{c}{ Foreign Aquirers } & \multicolumn{2}{c}{ Own Industry M\&A } \\
\hline 1998 & 8 & 7 & $(87.5 \%)$ & 1 & $(12.5 \%)$ & 7 & $(87.5 \%)$ \\
1999 & 35 & 29 & $(82.9 \%)$ & 7 & $(20.0 \%)$ & 11 & $(31.4 \%)$ \\
2000 & 30 & 11 & $(36.7 \%)$ & 9 & $(30.0 \%)$ & 9 & $(30.0 \%)$ \\
2001 & 66 & 21 & $(31.8 \%)$ & 18 & $(27.3 \%)$ & 35 & $(53.0 \%)$ \\
2002 & 64 & 17 & $(26.6 \%)$ & 9 & $(14.1 \%)$ & 35 & $(54.7 \%)$ \\
2003 & 43 & $(18.6 \%)$ & 22 & $(51.2 \%)$ & 27 & $(62.8 \%)$ \\
2004 & 64 & 18 & $(28.1 \%)$ & 24 & $(37.5 \%)$ & 32 & $(50.0 \%)$ \\
2005 & 107 & 23 & $(21.5 \%)$ & 38 & $(35.5 \%)$ & 63 & $(58.9 \%)$ \\
2006 & 90 & 11 & $(12.2 \%)$ & 37 & $(41.1 \%)$ & 45 & $(50.0 \%)$ \\
\hline Total & 507 & 145 & $(28.6 \%)$ & 165 & $(32.5 \%)$ & 264 & $(52.1 \%)$ \\
\hline
\end{tabular}

Source: Authors' calculation using data from Bloomberg.

Note: The sample includes all completed M\&As in China and India between 1998 and 2006. Targets refer to public, private, and subsidiary firms. Sample data consist of the announced deals with more than fifty percent of targeted stock holding ratio in this table. No lower bound for the total amount of deal value is set. The acquirers are all foreign and domestic listed firms except firms in the financial sector and utilities. Acquirers with more than two deals within five business operating days are excluded from the sample. 
Table 2. Number of Takeover Activities in China and India (1998-2006)

\section{(a) China}

\begin{tabular}{|c|c|c|c|c|c|c|c|}
\hline & \multicolumn{3}{|l|}{ Targets } & \multicolumn{4}{|c|}{ Acquirers } \\
\hline & $\mathrm{N}$ & $\%$ & $\begin{array}{l}\text { Publicly Listed } \\
\text { Targets (\%) }\end{array}$ & $\begin{array}{l}\text { Own Industry } \\
\text { Acquisitions (\%) }\end{array}$ & $\mathrm{N}$ & $\%$ & $\begin{array}{l}\text { Foreign } \\
\text { Aquirers (\%) }\end{array}$ \\
\hline Agriculture & 18 & $1.5 \%$ & $0.0 \%$ & $44.4 \%$ & 21 & $1.7 \%$ & $38.1 \%$ \\
\hline Aircraft & 4 & $0.3 \%$ & $0.0 \%$ & $100.0 \%$ & 6 & $0.5 \%$ & $33.3 \%$ \\
\hline Apparel & 3 & $0.2 \%$ & $0.0 \%$ & $66.7 \%$ & 19 & $1.6 \%$ & $31.6 \%$ \\
\hline Automobiles & 34 & $2.8 \%$ & $17.6 \%$ & $52.9 \%$ & 23 & $1.9 \%$ & $43.5 \%$ \\
\hline Business services & 98 & $8.1 \%$ & $1.0 \%$ & $35.7 \%$ & 62 & $5.1 \%$ & $58.1 \%$ \\
\hline Business supplies & 1 & $0.1 \%$ & $0.0 \%$ & $100.0 \%$ & 1 & $0.1 \%$ & $100.0 \%$ \\
\hline $\begin{array}{l}\text { Dusiness suppires } \\
\text { Chemicals }\end{array}$ & 43 & $\begin{array}{l}0.1 \% \% \\
3.5 \%\end{array}$ & $20.9 \%$ & $39.5 \%$ & 33 & $\begin{array}{l}0.7 \% \\
2.7 \%\end{array}$ & $\begin{array}{l}10.0 \% \% \\
45.5 \%\end{array}$ \\
\hline Computers & 51 & $4.2 \%$ & $3.9 \%$ & $27.5 \%$ & 46 & $3.8 \%$ & $50.0 \%$ \\
\hline Construction & 41 & $3.4 \%$ & $7.3 \%$ & $43.9 \%$ & $\begin{array}{l}40 \\
39\end{array}$ & $\begin{array}{l}3.0 \% \\
3.2 \%\end{array}$ & $41.0 \%$ \\
\hline Construction materials & 4 & $0.3 \%$ & $0.0 \%$ & $75.0 \%$ & 3 & $0.2 \%$ & $66.7 \%$ \\
\hline Consumer goods & 6 & $0.5 \%$ & $0.0 \%$ & $16.7 \%$ & 8 & $0.7 \%$ & $50.0 \%$ \\
\hline Defense & 2 & $0.2 \%$ & $0.0 \%$ & $50.0 \%$ & 5 & $0.4 \%$ & $0.0 \%$ \\
\hline Electrical equipment & 41 & $3.4 \%$ & $7.3 \%$ & $48.8 \%$ & 39 & $3.2 \%$ & $30.8 \%$ \\
\hline $\begin{array}{l}\text { Electronic equipment } \\
\text { Elentral }\end{array}$ & $\begin{array}{l}41 \\
64\end{array}$ & $\begin{array}{l}5.4 \% \\
5.3 \%\end{array}$ & $1.6 \%$ & $\begin{array}{l}40.0 \% \\
46.9 \%\end{array}$ & 68 & $5.6 \%$ & $\begin{array}{l}50.0 \% \\
83.8 \%\end{array}$ \\
\hline Entertainment & & $0.7 \%$ & $0.0 \%$ & $50.0 \%$ & 8 & $0.7 \%$ & $87.5 \%$ \\
\hline Fabricated products & 2 & $0.2 \%$ & $50.0 \%$ & $0.0 \%$ & 2 & $0.2 \%$ & $0.0 \%$ \\
\hline $\begin{array}{l}\text { Financial services } \\
\text { Final }\end{array}$ & 57 & $4.7 \%$ & $1.8 \%$ & $33.3 \%$ & 124 & $10.2 \%$ & $31.5 \%$ \\
\hline Food products & 59 & $4.9 \%$ & $1.7 \%$ & $44.1 \%$ & 35 & $2.9 \%$ & $51.4 \%$ \\
\hline Healthcare & 2 & $0.2 \%$ & $0.0 \%$ & $0.0 \%$ & 0 & $0.0 \%$ & N.A. \\
\hline Insurance & 0 & $0.0 \%$ & N.A. & N.A. & 0 & $0.0 \%$ & N.A. \\
\hline Machinery & 34 & $2.8 \%$ & $17.6 \%$ & $44.1 \%$ & 47 & $3.9 \%$ & $19.1 \%$ \\
\hline $\begin{array}{l}\text { Machninery } \\
\text { Measuring and control Equipment }\end{array}$ & $\begin{array}{l}54 \\
26\end{array}$ & $\begin{array}{l}2.1 \% \\
2.1 \%\end{array}$ & $\begin{array}{l}1.6 \% \\
3.8 \%\end{array}$ & $\begin{array}{l}44.1 \% \% \\
57.7 \%\end{array}$ & 20 & $\begin{array}{l}3.9 \% \\
1.6 \%\end{array}$ & $\begin{array}{l}19.1 \% \\
70.0 \%\end{array}$ \\
\hline Medical equipment & 21 & $1.7 \%$ & $9.5 \%$ & $33.3 \%$ & 21 & $1.7 \%$ & $38.1 \%$ \\
\hline Miscellaneous & 149 & $12.3 \%$ & $4.7 \%$ & $32.9 \%$ & 189 & $15.6 \%$ & $40.2 \%$ \\
\hline Nonmetallic mining & 11 & $0.9 \%$ & $0.0 \%$ & $72.7 \%$ & $\begin{array}{r}109 \\
9\end{array}$ & $\begin{array}{r}10.00 \% \\
0.7 \%\end{array}$ & $44.4 \%$ \\
\hline Personal service & 7 & $0.6 \%$ & $0.0 \%$ & $14.3 \%$ & 5 & $0.4 \%$ & $80.0 \%$ \\
\hline Petroleum and natural gas & 41 & $3.4 \%$ & $12.2 \%$ & $48.8 \%$ & 37 & $3.0 \%$ & $35.1 \%$ \\
\hline Pharmaceutical & 32 & $2.6 \%$ & $3.1 \%$ & $43.8 \%$ & 27 & $2.2 \%$ & $22.2 \%$ \\
\hline Printing and publishing & $\begin{array}{r}32 \\
8\end{array}$ & $0.7 \%$ & $0.0 \%$ & $25.0 \%$ & 8 & $0.7 \%$ & $37.5 \%$ \\
\hline 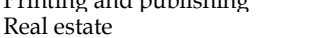 & 121 & $10.0 \%$ & $\begin{array}{l}0.0 \% \\
7.4 \%\end{array}$ & $39.7 \%$ & 79 & $\begin{array}{l}0.7 \% \\
6.5 \%\end{array}$ & $29.1 \%$ \\
\hline Recreational product & 5 & $0.4 \%$ & $0.0 \%$ & $20.0 \%$ & 6 & $0.5 \%$ & $16.7 \%$ \\
\hline Restaurants, motels, hotels & 6 & $0.5 \%$ & $0.0 \%$ & $0.0 \%$ & 3 & $0.2 \%$ & $0.0 \%$ \\
\hline $\begin{array}{l}\text { Retail } \\
\text { Retal }\end{array}$ & 25 & $2.1 \%$ & $12.0 \%$ & $32.0 \%$ & 41 & $3.4 \%$ & $43.9 \%$ \\
\hline Rubber and plastics & 8 & $0.7 \%$ & $12.5 \%$ & $75.0 \%$ & 8 & $0.7 \%$ & $50.0 \%$ \\
\hline Shipbuilding, railroad & 1 & $0.1 \%$ & $0.0 \%$ & $0.0 \%$ & 0 & $0.0 \%$ & N.A. \\
\hline Shipping containers & 3 & $0.2 \%$ & $0.0 \%$ & $66.7 \%$ & & $0.7 \%$ & $33.3 \%$ \\
\hline Steel works & 38 & $3.1 \%$ & $2.6 \%$ & $57.9 \%$ & 35 & $2.9 \%$ & $11.4 \%$ \\
\hline Telecommunications & $\begin{array}{l}30 \\
95\end{array}$ & $\begin{array}{l}3.110 \\
7.8 \%\end{array}$ & $\begin{array}{l}2.0 \% \\
3.2 \%\end{array}$ & $56.8 \%$ & $\begin{array}{l}50 \\
87\end{array}$ & $\begin{array}{l}2.9 \% \\
7.2 \%\end{array}$ & $\begin{array}{l}11.4 \% \\
55.2 \%\end{array}$ \\
\hline Textiles & 26 & $2.1 \%$ & $11.5 \%$ & $23.1 \%$ & 14 & $1.2 \%$ & $42.9 \%$ \\
\hline Tradi & 9 & $0.7 \%$ & $0.0 \%$ & $22.2 \%$ & 11 & $0.9 \%$ & $18.2 \%$ \\
\hline Trar & 0 & $0.0 \%$ & N.A. & N.A. & 0 & $0.0 \%$ & N.A. \\
\hline Trash and waste & 0 & $0.0 \%$ & $\begin{array}{l}\text { N.A. } \\
\text { N.A. }\end{array}$ & $\begin{array}{l}\text { N.A. } \\
\text { N.A. }\end{array}$ & 3 & $\begin{array}{l}0.2 \% \\
0.2 \%\end{array}$ & $\begin{array}{l}\text { N.A. } \\
100.0 \%\end{array}$ \\
\hline Wholesale & 10 & $0.8 \%$ & $0.0 \%$ & $50.0 \%$ & 13 & $1.1 \%$ & $61.5 \%$ \\
\hline Total & 2141 & $00.0 \%$ & & & 214 & $100.0 \%$ & \\
\hline
\end{tabular}

Source: Authors' calculation using data from Bloomberg

Note: This table reports, by industry, the fraction of sample firms that were acquired in 1998-2006. Targets refer to public, private, and subsidiary firms. Industry data are organized using

Fama and French (1997) industry classifications. Columns 3 and 7 report the number and percentage of acquirers and targets, respectively, in a particular industry. Columns 4 and 5 report percentage of targets publicly listed and acquired by firms in the same industry, respectively.

(b) India

\begin{tabular}{|c|c|c|c|c|c|c|c|}
\hline & \multicolumn{3}{|c|}{ Targets } & \multicolumn{4}{|c|}{ Acquirers } \\
\hline & $\mathrm{N}$ & $\%$ & $\begin{array}{l}\text { Publicly Listed } \\
\text { Targets (\%) }\end{array}$ & $\begin{array}{l}\text { Own Industry } \\
\text { Acquisitions(\%) }\end{array}$ & $\mathrm{N}$ & $\%$ & $\begin{array}{l}\text { Foreign } \\
\text { Aquirers(\%) }\end{array}$ \\
\hline Agriculture & 11 & $2.2 \%$ & $36.4 \%$ & $36.4 \%$ & 11 & $2.2 \%$ & $27.3 \%$ \\
\hline Aircraft & 0 & $0.0 \%$ & N.A. & N.A. & 0 & $0.0 \%$ & N.A. \\
\hline Apparel & 1 & $0.2 \%$ & $0.0 \%$ & $0.0 \%$ & 0 & $0.0 \%$ & N.A. \\
\hline Automobiles & 16 & $3.2 \%$ & $31.3 \%$ & $56.3 \%$ & 19 & $3.7 \%$ & $21.1 \%$ \\
\hline Business services & 34 & $6.7 \%$ & $44.1 \%$ & $55.9 \%$ & 47 & $9.3 \%$ & $34.0 \%$ \\
\hline Business supplies & 44 & $8.7 \%$ & $0.0 \%$ & $0.0 \%$ & 38 & $7.5 \%$ & $0.0 \%$ \\
\hline Chemicals & 0 & $0.0 \%$ & N.A. & N.A. & 0 & $0.0 \%$ & N.A. \\
\hline Computers & 16 & $3.2 \%$ & $56.3 \%$ & $56.3 \%$ & 18 & $3.6 \%$ & $22.2 \%$ \\
\hline Construction & 44 & $8.7 \%$ & $13.6 \%$ & $50.0 \%$ & 45 & $8.9 \%$ & $26.7 \%$ \\
\hline Construction materials & 16 & $3.2 \%$ & $56.3 \%$ & $93.8 \%$ & 17 & $3.4 \%$ & $17.6 \%$ \\
\hline Consumer goods & 2 & $0.4 \%$ & $0.0 \%$ & $100.0 \%$ & 4 & $0.8 \%$ & $0.0 \%$ \\
\hline Defense & 3 & $0.6 \%$ & $0.0 \%$ & $0.0 \%$ & 3 & $0.6 \%$ & $0.0 \%$ \\
\hline Electrical equipment & 0 & $0.0 \%$ & N.A. & N.A. & 0 & $0.0 \%$ & N.A. \\
\hline Electronic equipment & 10 & $2.0 \%$ & $20.0 \%$ & $60.0 \%$ & 9 & $1.8 \%$ & $11.1 \%$ \\
\hline Entertainment & 12 & $2.4 \%$ & $33.3 \%$ & $58.3 \%$ & 19 & $3.7 \%$ & $52.6 \%$ \\
\hline Fabricated products & 1 & $0.2 \%$ & $0.0 \%$ & $0.0 \%$ & 1 & $0.2 \%$ & $0.0 \%$ \\
\hline Financial Services & 2 & $0.4 \%$ & $0.0 \%$ & $100.0 \%$ & 2 & $0.4 \%$ & $50.0 \%$ \\
\hline Food products & 32 & $6.3 \%$ & $28.1 \%$ & $81.3 \%$ & 29 & $5.7 \%$ & $27.6 \%$ \\
\hline Healthcare & 0 & $0.0 \%$ & N.A. & N.A. & 0 & $0.0 \%$ & N.A. \\
\hline Insurance & 0 & $0.0 \%$ & N.A. & N.A. & 0 & $0.0 \%$ & N.A. \\
\hline Machinery & 6 & $1.2 \%$ & $33.3 \%$ & $16.7 \%$ & 9 & $1.8 \%$ & $22.2 \%$ \\
\hline Measuring and control Equipment & & $1.8 \%$ & $22.2 \%$ & $55.6 \%$ & 7 & $1.4 \%$ & $71.4 \%$ \\
\hline Medical equipment & 12 & $2.4 \%$ & $0.0 \%$ & $41.7 \%$ & 8 & $1.6 \%$ & $62.5 \%$ \\
\hline Miscellaneous & 102 & $20.1 \%$ & $10.8 \%$ & $13.7 \%$ & 78 & $15.4 \%$ & $24.4 \%$ \\
\hline Nonmetallic mining & 0 & $0.0 \%$ & N.A. & N.A. & 0 & $0.0 \%$ & N.A. \\
\hline Personal service & 5 & $1.0 \%$ & $0.0 \%$ & $40.0 \%$ & 4 & $0.8 \%$ & $100.0 \%$ \\
\hline Petroleum and natural gas & 13 & $2.6 \%$ & $53.8 \%$ & $46.2 \%$ & 19 & $3.7 \%$ & $26.3 \%$ \\
\hline Pharmaceutical & 28 & $5.5 \%$ & $42.9 \%$ & $75.0 \%$ & 33 & $6.5 \%$ & $9.1 \%$ \\
\hline Printing and Publishing & 2 & $0.4 \%$ & $0.0 \%$ & $100.0 \%$ & 2 & $0.4 \%$ & $50.0 \%$ \\
\hline Real estate & 4 & $0.8 \%$ & $0.0 \%$ & $25.0 \%$ & 1 & $0.2 \%$ & $100.0 \%$ \\
\hline Recreational products & 0 & $0.0 \%$ & N.A. & N.A. & 0 & $0.0 \%$ & N.A. \\
\hline Restaurants, motels, hotels & 4 & $0.8 \%$ & $25.0 \%$ & $50.0 \%$ & 2 & $0.4 \%$ & $0.0 \%$ \\
\hline Retail & 4 & $0.8 \%$ & $0.0 \%$ & $50.0 \%$ & 4 & $0.8 \%$ & $25.0 \%$ \\
\hline Rubber and plastics & 2 & $0.4 \%$ & $0.0 \%$ & $50.0 \%$ & 3 & $0.6 \%$ & $0.0 \%$ \\
\hline Shipbuilding, railroad & 0 & $0.0 \%$ & N.A. & N.A. & 0 & $0.0 \%$ & N.A. \\
\hline Shipping Containers & 3 & $0.6 \%$ & $66.7 \%$ & $33.3 \%$ & 3 & $0.6 \%$ & $33.3 \%$ \\
\hline Steel works & 19 & $3.7 \%$ & $42.1 \%$ & $89.5 \%$ & 30 & $5.9 \%$ & $20.0 \%$ \\
\hline Telecommunications & 30 & $5.9 \%$ & $10.0 \%$ & $66.7 \%$ & 25 & $4.9 \%$ & $56.0 \%$ \\
\hline Textiles & 19 & $3.7 \%$ & $36.8 \%$ & $31.6 \%$ & 14 & $2.8 \%$ & $0.0 \%$ \\
\hline Trading & 0 & $0.0 \%$ & N.A. & N.A. & 0 & $0.0 \%$ & N.A. \\
\hline Transportation & 0 & $0.0 \%$ & N.A. & N.A. & 0 & $0.0 \%$ & N.A. \\
\hline Trash and waste & 0 & $0.0 \%$ & N.A. & N.A. & 0 & $0.0 \%$ & N.A. \\
\hline Wholesale & 1 & $0.2 \%$ & $0.0 \%$ & $0.0 \%$ & 3 & $0.6 \%$ & $33.3 \%$ \\
\hline
\end{tabular}


Table 3. Empirical Results of Characteristics of Targets

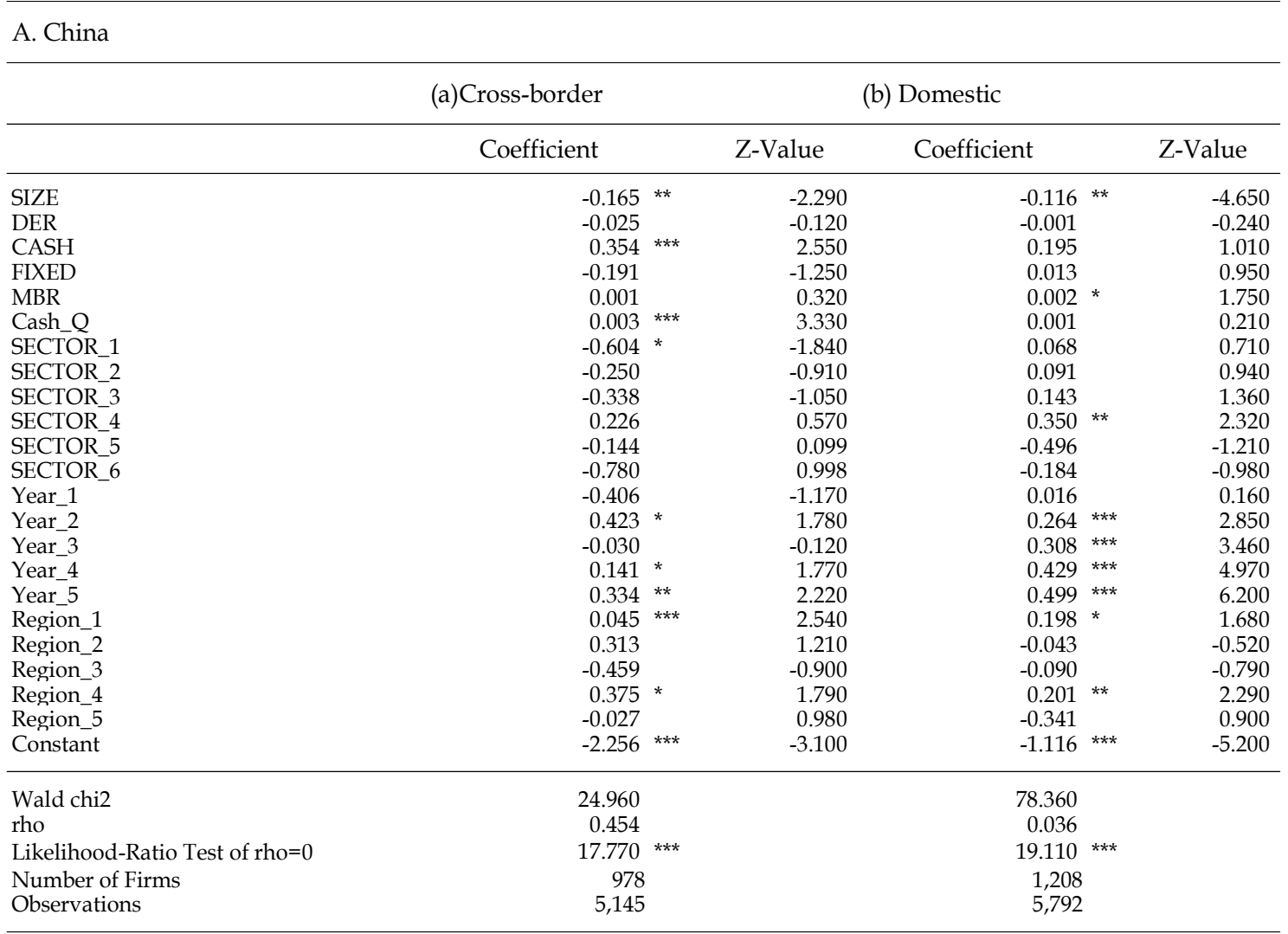

B. India

(a)Cross-border

(b) Domestic

\begin{tabular}{|c|c|c|c|c|c|c|}
\hline & Coefficient & & Z-Value & Coefficient & & Z-Value \\
\hline SIZE & 0.062 & & 1.280 & 0.100 & $* *$ & 2.260 \\
\hline DER & -0.039 & * & -1.780 & -0.031 & & -1.480 \\
\hline CASH & 0.769 & * & 1.880 & 0.638 & * & 1.710 \\
\hline FIXED & 0.007 & & 0.480 & -0.008 & & -0.290 \\
\hline MBR & 0.003 & & 0.410 & 0.004 & & 0.030 \\
\hline Cash_Q & 0.089 & $* * *$ & 2.620 & 0.410 & * & 1.770 \\
\hline SECTOR_1 & 0.196 & & 0.960 & -0.267 & & -1.180 \\
\hline SECTOR_2 & 0.006 & & 0.030 & -0.065 & & -0.290 \\
\hline SECTOR_3 & 0.214 & & 0.950 & -0.040 & & -0.180 \\
\hline SECTOR_4 & -0.763 & & -0.987 & -0.845 & & 1.000 \\
\hline SECTOR_5 & -0.523 & & -1.000 & 0.420 & ** & 2.180 \\
\hline SECTOR_6 & -0.064 & & -0.230 & 0.382 & * & 1.750 \\
\hline Year_1 & 0.852 & ** & 1.990 & -0.153 & & -0.650 \\
\hline Year_2 & 0.491 & & 1.080 & 0.219 & & 1.380 \\
\hline Year_3 & 0.134 & & 0.270 & -0.136 & & -0.630 \\
\hline Year_4 & 0.235 & & 0.550 & 0.123 & & 0.360 \\
\hline Year_5 & -0.113 & & -0.350 & 0.339 & & 1.480 \\
\hline Region_1 & 0.038 & & 0.170 & -0.153 & & -0.650 \\
\hline Region_2 & 0.139 & & 0.850 & 0.219 & & 1.380 \\
\hline Region_3 & 0.152 & & 0.830 & -0.136 & & -0.630 \\
\hline Region_4 & -0.528 & & -0.100 & 0.123 & & 0.360 \\
\hline Region_5 & -0.113 & & -0.350 & 0.358 & & 1.480 \\
\hline Constant & -2.829 & $* * *$ & -5.550 & -3.292 & $* * *$ & -6.200 \\
\hline Wald chi2 & 22.210 & & & 32.330 & & \\
\hline rho & 0.223 & & & 0.148 & & \\
\hline Likelihood-Ratio Test of rho=0 & 7.520 & $* * *$ & & 2.060 & * & \\
\hline Number of Firms & 861 & & & 924 & & \\
\hline Observations & 4,470 & & & 4,562 & & \\
\hline
\end{tabular}

Notes: 
1. This table represents the results of a tobit estimation that predicts which firms will be targeted in a given year. The empirical model employs the announced targeted stock holding ratio by an acquirer as a dependent variable when the firm is the target of an acquisition attempt and others are 0 in year $t$. The independent variable is one year lagged financial data of a three-year average. Therefore, the dependent variables are virtually the announced deals in 2001-2006. SIZE is the natural logarithm of total assets, DER is the total liability divided by market valued capital, CASH is cash reserves divided by total assets, FIXED is fixed assets divided by total assets, ROA is return on assets, MBR is book value of total liability plus market valued capital divided by book value of total assets.

2. ***, ** and * denotes significance at 1,5 and 10 percent level, respectively.

3. In this estimation, six categories of industrial dummy variables are added based on a definition of Bloomberg's "Industrial Sector Level I," i.e., Dum1: "Basic materials," Dum2: “Communications," Dum3: "Consumer goods-cyclical," Dum4: "Consumer goods-non cyclical," Dum5: "Industrial" and Dum6: "Technology". The definition is different from that of table 2.

4. Five regional dummy variables for Chinese firms are set as follows. Region_1: A headquarter of the firm locates in Beijing and Shanghai, Region_2: Fujian, GuangDong and Zhejiang, Region_3: Chilin, Liaoning and Heilongjiang, Region_4: Shandong and Hebei, Region_4: Hunan, Hubei, Henan and Shanxi, Region_5: Sichuan, Guizhou and Chongqing.

5. Five regional dummy variables for Indian firms are as follows. Region_1: A headquarter of the firm locates in New Delhi, Mumbai, Bangalore and Chennai, Region_2: Maharashtra and Karnataka, Region_3: Tamil Nadu and Andra Pradesh, Region_4: Orissa and West Bengal, Region_4: Gujarat and Rajasthan, Region_5: Haryana and Punjab. 
Table 4. Cumulative Abnormal Returns of Acquirers by Type of Acquisitions

\section{A. China}

(a) Cumulative Abnormal Returns of Acquirers of Cross-border and Domestic M\&A

\begin{tabular}{|c|c|c|c|c|c|c|c|c|c|}
\hline & & $\begin{array}{l}\text { All } \\
\text { (1) }\end{array}$ & & $\begin{array}{l}\text { Cross-border } \\
\text { (2) }\end{array}$ & & $\begin{array}{l}\text { Domestic } \\
\text { (3) }\end{array}$ & & $\begin{array}{l}\text { Difference } \\
(2)-(3)\end{array}$ & \\
\hline$(-1,1)$ & $\begin{array}{l}\text { Mean } \\
\text { Median }\end{array}$ & $\begin{array}{l}1.70 \%^{*+* t+} \\
0.81 \%^{*+*}\end{array}$ & $\begin{array}{l}{[4.00]} \\
{[4.41]}\end{array}$ & $\begin{array}{l}2.47 \%^{* * *} \\
1.24 \%^{* *}\end{array}$ & $\begin{array}{l}{[3.57]} \\
{[2.39]}\end{array}$ & $\begin{array}{l}0.51 \%^{* *} \\
0.21 \%^{* * *}\end{array}$ & $\begin{array}{l}{[2.22]} \\
{[3.71]}\end{array}$ & $\begin{array}{l}2.50 \% \text { *** } \\
1.03 \% \text { * }\end{array}$ & $\begin{array}{l}{[2.77]} \\
{[1.76]}\end{array}$ \\
\hline$(-20,20)$ & $\begin{array}{l}\text { Mean } \\
\text { Median }\end{array}$ & $\begin{array}{l}4.92 \% \\
2.13 \%\end{array}$ & $\begin{array}{l}{[3.20]} \\
\lceil 3.24\rceil\end{array}$ & $\begin{array}{l}7.92 \% \text { * } \\
3.42 \% \text { * }\end{array}$ & $\begin{array}{l}\lceil 1.90] \\
\lceil 1.65\rceil\end{array}$ & $\begin{array}{l}0.66 \% \\
0.34 \%\end{array}$ & $\begin{array}{l}{[1.20]} \\
\lceil 1.15\rceil\end{array}$ & $\begin{array}{l}7.26 \% \text { * } \\
3.08 \% \text { * }\end{array}$ & $\begin{array}{l}{[1.70]} \\
\lceil 1.60\end{array}$ \\
\hline & Observations & 828 & & 484 & & 344 & & & \\
\hline
\end{tabular}

(b) Cumulative Abnormal Returns of Acquirers by Type of Targets

\begin{tabular}{|c|c|c|c|c|c|c|c|c|c|c|}
\hline & & & $\begin{array}{l}\text { All } \\
(1)\end{array}$ & & $\begin{array}{l}\text { Public Target } \\
\text { (2) }\end{array}$ & & $\begin{array}{l}\text { Private Target } \\
\text { (3) }\end{array}$ & & $\begin{array}{l}\text { Difference } \\
\text { (2)-(3) }\end{array}$ & \\
\hline$(-1,1)$ & Cross-border & $\begin{array}{l}\text { Mean } \\
\text { Median }\end{array}$ & $\begin{array}{l}2.47 \% \%^{* * * *} \\
1.24 \% * *\end{array}$ & {$[3.57]$} & $\begin{array}{l}1.84 \% \text { ** } \\
0.94 \%\end{array}$ & {$[2.35]$} & $\begin{array}{l}2.55 \% \%^{* * * *} \\
1.23 \%^{* * *}\end{array}$ & {$[3.76]$} & $\begin{array}{l}-0.71 \% \text { ** } \\
-0.29 \%\end{array}$ & $\begin{array}{l}{[2.11]} \\
{[0.12]}\end{array}$ \\
\hline$(-20,20)$ & Cross-border & $\begin{array}{l}\text { Mean } \\
\text { Median }\end{array}$ & $\begin{array}{l}7.92 \%{ }^{*} \\
3.42 \%^{*}\end{array}$ & $\begin{array}{l}{[1.90]} \\
{[1.65]}\end{array}$ & $\begin{array}{l}4.85 \% \\
2.98 \%\end{array}$ & $\begin{array}{l}{[1.58]} \\
{[1.05]}\end{array}$ & $\begin{array}{l}8.31 \%{ }^{* *} \\
3.44 \%\end{array}$ & $\begin{array}{l}{[2.11]} \\
{[0.79]}\end{array}$ & $\begin{array}{l}-3.46 \%{ }^{*} \\
-0.46 \%\end{array}$ & $\begin{array}{l}{[1.71]} \\
{[0.19]}\end{array}$ \\
\hline & Observations & & 484 & & 17 & & 467 & & & \\
\hline
\end{tabular}

(c) Cumulative Abnormal Returns of Acquirers by Type of Industrial Sector

\begin{tabular}{|c|c|c|c|c|c|c|c|c|c|c|}
\hline \multirow[b]{2}{*}{$(-1,1)$} & \multirow[b]{2}{*}{ Cross-border } & \multicolumn{2}{|c|}{$\begin{array}{l}\text { All } \\
(1)\end{array}$} & \multirow[b]{2}{*}{$\begin{array}{l}{[3.57]} \\
{[2.39]}\end{array}$} & \multirow{2}{*}{\begin{tabular}{l} 
Own-Industry \\
(2) \\
\multicolumn{1}{|c}{$4.44 \%$ ** } \\
$1.93 \%$
\end{tabular}} & \multirow[b]{2}{*}{$\begin{array}{l}{[1.97]} \\
{[1.09]}\end{array}$} & \multicolumn{2}{|c|}{$\begin{array}{l}\text { Non-Own Industry } \\
\text { (3) }\end{array}$} & \multicolumn{2}{|l|}{ (2)-(3) } \\
\hline & & $\begin{array}{l}\text { Mean } \\
\text { Median }\end{array}$ & $\begin{array}{l}2.47 \% \\
1.24 \%\end{array}$ & & & & $\begin{array}{l}2.11 \% \\
1.10 \%\end{array}$ & $\begin{array}{l}{[3.86]} \\
{[3.11]}\end{array}$ & $\begin{array}{l}2.33 \% \\
0.83 \%\end{array}$ & $\begin{array}{l}{[2.56]} \\
{[0.31]}\end{array}$ \\
\hline$(-20,20)$ & Cross-border & $\begin{array}{l}\text { Mean } \\
\text { Median }\end{array}$ & $\begin{array}{l}7.92 \% \text { * } \\
3.42 \% \text { * }\end{array}$ & $\begin{array}{l}{[1.90]} \\
{[1.65]}\end{array}$ & $\begin{array}{c}11.45 \% \text { * } \\
4.87 \% \text { }\end{array}$ & $\begin{array}{l}{[2.00]} \\
{[1.31]}\end{array}$ & $\begin{array}{l}7.24 \% \text { * } \\
3.16 \% \text { * }\end{array}$ & $\begin{array}{l}{[1.77]} \\
{[1.84]}\end{array}$ & $\begin{array}{l}4.21 \% \text { * } \\
1.71 \%\end{array}$ & $\begin{array}{l}{[2.05]} \\
{[0.15]}\end{array}$ \\
\hline & Observations & & 484 & & 73 & & 411 & & & \\
\hline
\end{tabular}

Notes:

1. Cumulative abnormal returns for acquirers are calculated for the three-day $(-1,1)$ and 40 one-day $(-20$, 20) events around the announcement of a takeover. Abnormal returns are estimated using market index returns of mother country market of each acquirer. The parameters for the market model are estimated over the $(-256,-21)$ interval. All acquirers are publicly traded listed on the domestic/foreign stock exchange.

2. Each industrial sector of the sample deal is defined based on Table 2 .

3. *** denotes significance at 1 percent level, ${ }^{* *}$ denotes significance at 5 percent level and * denotes significance at 10 percent level.

4.B. India

(a) Cumulative Abnormal Returns of Acquirers of Cross-border and Domestic M\&A

\begin{tabular}{|c|c|c|c|c|c|c|c|c|c|}
\hline & & $\begin{array}{l}\text { All } \\
\text { (1) }\end{array}$ & & $\begin{array}{l}\text { Cross-border } \\
\text { (2) }\end{array}$ & & $\begin{array}{l}\text { Domestic } \\
\text { (3) }\end{array}$ & & $\begin{array}{l}\text { Difference } \\
\text { (2)-(3) }\end{array}$ & \\
\hline$(-1,1)$ & $\begin{array}{l}\text { Mean } \\
\text { Median }\end{array}$ & $\begin{array}{l}1.20 \% \text { * } \\
0.55 \% \text { * }\end{array}$ & $\begin{array}{l}{[2.95]} \\
{[1.68]}\end{array}$ & $\begin{array}{l}1.96 \% \text { ** } \\
0.92 \% \text { ** }\end{array}$ & $\begin{array}{l}{[1.99]} \\
{[2.20]}\end{array}$ & $\begin{array}{l}0.99 \%^{* * *} \\
0.40 \%\end{array}$ & $\begin{array}{l}{[3.11]} \\
{[2.05]}\end{array}$ & $\begin{array}{l}0.97 \% \text { *** } \\
0.52 \% \text { **t }\end{array}$ & $\begin{array}{l}{[2.95]} \\
{[3.11]}\end{array}$ \\
\hline \multirow[t]{2}{*}{$(-20,20)$} & $\begin{array}{l}\text { Mean } \\
\text { Median }\end{array}$ & $\begin{array}{l}5.33 \% \\
2.16 \%\end{array}$ & $\begin{array}{l}{[2.86]} \\
{[1.70]}\end{array}$ & $\begin{array}{l}9.88 \% \text { * } \\
4.33 \% \text { * }\end{array}$ & $\begin{array}{l}{[1.70]} \\
{[1.81]}\end{array}$ & $\begin{array}{l}3.45 \% \text { ** } \\
1.27 \%\end{array}$ & $\begin{array}{l}{[1.98]} \\
{[1.10]}\end{array}$ & $\begin{array}{l}6.43 \% \text { *** } \\
3.06 \% \text { * }\end{array}$ & $\begin{array}{l}{[3.00]} \\
{[1.88]}\end{array}$ \\
\hline & Observations & 489 & & 143 & & 346 & & & \\
\hline
\end{tabular}

(b) Cumulative Abnormal Returns of Acquirers by Type of Targets 


\begin{tabular}{|c|c|c|c|c|c|c|c|c|c|c|}
\hline \multirow[b]{2}{*}{$(-1,1)$} & \multirow[b]{2}{*}{ Cross-border } & \multicolumn{2}{|c|}{$\begin{array}{l}\text { All } \\
\text { (1) }\end{array}$} & \multicolumn{2}{|c|}{$\begin{array}{l}\text { Public } \\
(2)\end{array}$} & \multicolumn{2}{|c|}{$\begin{array}{l}\text { Private } \\
\text { (3) }\end{array}$} & \multicolumn{3}{|c|}{$\begin{array}{l}\text { Difference } \\
\text { (2)-(3) }\end{array}$} \\
\hline & & $\begin{array}{l}\text { Mean } \\
\text { Median }\end{array}$ & $\begin{array}{l}1.96 \% \text { ** } \\
0.92 \% \text { ** }\end{array}$ & $\begin{array}{l}{[1.99]} \\
{[2.20]}\end{array}$ & $\begin{array}{l}0.90 \% \\
0.13 \%\end{array}$ & $\begin{array}{l}{[1.41]} \\
{[1.12]}\end{array}$ & $\begin{array}{l}2.76 \% \text { * } \\
1.16 \% \text { * }\end{array}$ & $\begin{array}{l}{[2.02]} \\
{[1.99]}\end{array}$ & $\begin{array}{l}-1.86 \% \text { * } \\
-1.03 \% \text { * }\end{array}$ & $\begin{array}{l}{[-2.00]} \\
{[-1.91]}\end{array}$ \\
\hline$(-20,20)$ & Cross-border & $\begin{array}{l}\text { Mean } \\
\text { Median }\end{array}$ & $\begin{array}{l}9.88 \% \text { * } \\
4.33 \% \text { * }\end{array}$ & $\begin{array}{l}{[1.70]} \\
{[1.81]}\end{array}$ & $\begin{array}{l}8.93 \% \\
3.61 \%\end{array}$ & $\begin{array}{l}{[1.10]} \\
{[0.69]}\end{array}$ & $\begin{array}{c}10.53 \% \text { * } \\
4.53 \%\end{array}$ & $\begin{array}{l}{[1.88]} \\
{[1.21]}\end{array}$ & $\begin{array}{l}-1.60 \% \text { ** } \\
-0.92 \%\end{array}$ & $\begin{array}{l}{[-2.02]} \\
{[-0.96]}\end{array}$ \\
\hline & Observations & & 143 & & 31 & & 112 & & & \\
\hline
\end{tabular}

(c) Cumulative Abnormal Returns of Acquirers by Type of Industrial Sector

\begin{tabular}{|c|c|c|c|c|c|c|c|c|c|c|}
\hline & & & & & $\begin{array}{l}\text { Own-Industry } \\
\text { (2) }\end{array}$ & & $\begin{array}{l}\text { Non-Own Inc } \\
\text { (3) }\end{array}$ & & $(2)-(3)$ & \\
\hline$(-1,1)$ & Cross-border & $\begin{array}{l}\text { Mean } \\
\text { Median }\end{array}$ & $\begin{array}{l}1.96 \% \text { ** } \\
0.92 \% \text { * }\end{array}$ & $\begin{array}{l}{[1.99]} \\
{[2.20]}\end{array}$ & $\begin{array}{l}3.20 \% \\
1.44 \%\end{array}$ & $\begin{array}{l}{[1.11]} \\
{[0.47]}\end{array}$ & $\begin{array}{l}1.39 \% \text { ** } \\
0.68 \% \text { * }\end{array}$ & $\begin{array}{l}{[2.01]} \\
{[2.21]}\end{array}$ & $\begin{array}{l}1.81 \% \text { ** } \\
0.76 \% \text { * }\end{array}$ & $\begin{array}{l}{[2.05]} \\
{[1.62]}\end{array}$ \\
\hline$(-20,20)$ & Cross-border & $\begin{array}{l}\text { Mean } \\
\text { Median }\end{array}$ & $\begin{array}{l}9.88 \% \text { * } \\
4.33 \% \text { * }\end{array}$ & $\begin{array}{l}{[1.70]} \\
{[1.81]}\end{array}$ & $\begin{array}{r}13.97 \% \\
5.62 \%\end{array}$ & $\begin{array}{l}{[1.19]} \\
{[0.33]}\end{array}$ & $\begin{array}{l}8.02 \% \text { *** } \\
3.96 \% \text { * }\end{array}$ & $\begin{array}{l}{[3.11]} \\
{[1.80]}\end{array}$ & $\begin{array}{l}5.95 \% \text { * } \\
1.66 \%\end{array}$ & $\begin{array}{l}{[1.98]} \\
{[0.61]}\end{array}$ \\
\hline
\end{tabular}

Notes:

1. Cumulative abnormal returns for acquirers are calculated for the three-day $(-1,1)$ and forty one-day $(-20,20)$ event around the announcement of a takeover. Abnormal returns are estimated using market index returns of mother country market of each acquirer. The parameters for the market model are estimated over the $(-256,-21)$ interval. All acquirers are publicly traded listed on the domestic/foreign stock exchange.

2. Each industrial sector of the sample deal is defined based on Table 2.

3. *** denotes significance at 1 percent level, ** denotes significance at 5 percent level and * denotes significance at 10 percent level. 
Table 5. Empirical Results of Determinants of Cumulative Abnormal Returns

(A) China

(a) Foreign Acquirer's CARs

(b)Domest Target's CARs

\begin{tabular}{|c|c|c|c|c|c|}
\hline & Coefficient & Z-Value & Coefficient & & Z-Value \\
\hline RSIZE & $-4.760 \mathrm{E}-07$ & -0.100 & $-4.270 \mathrm{E}-06$ & & -0.450 \\
\hline MBR_A & 0.001 & 0.260 & 3.733E-04 & & 0.040 \\
\hline MBR_A/MBR_T & 0.002 & 0.550 & 0.016 & ** & 2.410 \\
\hline MBR_A*Cash_T & $0.093 * * *$ & 3.150 & 0.116 & $* *$ & 2.010 \\
\hline Ownēship & 4.934E-04 *** & 6.880 & 0.001 & $* * *$ & 10.040 \\
\hline Year00 & $-0.009 *$ & -1.720 & -0.022 & $* *$ & -2.160 \\
\hline Year01 & $-0.014 * *$ & -2.430 & -0.019 & & -1.620 \\
\hline Year02 & $-0.011 * *$ & -2.270 & -0.015 & & -1.490 \\
\hline Year03 & 0.005 & 1.020 & -0.002 & & -0.280 \\
\hline Year04 & $3.464 \mathrm{E}-04$ & 0.040 & -0.003 & & -0.220 \\
\hline Constant & 0.003 & 0.070 & -0.004 & $* * *$ & -0.470 \\
\hline LR Chi2 & $63.610 * * *$ & & 94.290 & *** & \\
\hline Pseudo R2 & 0.068 & & 0.142 & & \\
\hline Observations & 177 & & 177 & & \\
\hline
\end{tabular}

Notes:

1. Tobit estimation of the acquirer's and target's three-day cumulative abnormal return on the following variables: RSIZE: natural logarithm of total assets of acquirer divided by that of target in terms of US dollar, MBR_A and MBR_T are book value of total liability plus market value of capital divided by total assets for acquirer and target, respectively. CASH_T is cash reserve divided by total assets of target. Ownership is targeted stock holding ratio of target by acquirer announced.

2. Each industrial sector of the sample deal is defined based on Table 2.

3. *** denotes significance at 1 percent level, ** denotes significance at 5 percent level and * denotes significance at 10 percent level.

(B) India

(a) Foreign Acquirer's CARs

(b)Domest Target's CARs

\begin{tabular}{|c|c|c|c|c|}
\hline & Coefficient & Z-Value & Coefficient & Z-Value \\
\hline RSIZE & $6.600 \mathrm{E}-08$ & 0.310 & $2.010 \mathrm{E}-08$ & 0.210 \\
\hline MBR_A & -0.002 & -1.580 & $-0.001 *$ & -1.680 \\
\hline MBR_A/MBR_T & $2.547 \mathrm{E}-04$ & 0.350 & $-5.650 \mathrm{E}-05$ & -0.170 \\
\hline MBR_A*Cash_T & $0.005 *$ & 1.720 & 0.003 ** & 2.100 \\
\hline Ownērship & $0.001 * * *$ & 6.130 & $0.002 * * *$ & 19.180 \\
\hline Year00 & -0.007 & -1.600 & $0.004 * *$ & 2.140 \\
\hline Year01 & $-0.008 * *$ & -2.540 & -0.002 & -1.420 \\
\hline Year02 & $-0.006 *$ & -1.670 & -0.001 & -0.460 \\
\hline Year03 & $-0.008 * *$ & -2.090 & -0.001 & -0.820 \\
\hline Year04 & $-5.559 \mathrm{E}-03$ * & -1.650 & $-0.004 * *$ & -2.340 \\
\hline Constant & $0.010^{* * *}$ & 2.910 & 0.003 ** & 2.020 \\
\hline LR Chi2 & $43.790 * * *$ & & $313.100 * * *$ & \\
\hline Pseudo R2 & 0.014 & & 0.074 & \\
\hline Observations & 776 & & 776 & \\
\hline
\end{tabular}

Notes:

1. Tobit estimation of the acquirer's three day cumulative abnormal return on the on the following variables. RSIZE: natural logarithm of total assets of acquirer divided by that of target in terms of US dollar. MBR_A and MBR_T are book value of total liability plus market value of capital divided by total assets for acquirer and target, respectively. CASH_T is cash reserve divided by total assets of target. 
Ownership is targeted stock holding ratio of target by acquirer announced.

2. Each industrial sector of the sample deal is defined based on Table 2 .

3. *** denotes significance at 1 percent level, ${ }^{* *}$ denotes significance at 5 percent level and * denotes significance at 10 percent level. 
APPENDIX 1. Cumulative Abnormal Returns of Targets of Cross-border and Domestic M\&A

Tables A.a and A.b show the three-day cumulative abnormal returns (CARs) of targets classified by cross-border and domestic deals(?) in China and India. In the tables, CARs of full targets sample is significantly negative in China. However, when we separate the target samples we find contradictory results between cross-border and domestic deals. We find that the CARs is significantly positive for cross-border deals, and significantly negative for the domestic. As shown in the table, a foreign acquirer significantly increases shareholder's value in China, while a domestic acquirer reduces the shareholder's value. In India, the results for all samples show that CARs of both cross-border and domestic are significantly positive, and cross-border is not significantly different from domestic acquisition. Empirical results suggest that either domestic or cross-border acquisition can bring significant additional shareholder's value in India. The methodology used in the tables below is same as that of the second empirical analysis in this paper. We show this empirical results to point out that cross-border deals also provide merits to shareholders of targets. The third empirical analysis also uses the CAR of each individual firm.

A. China

\begin{tabular}{|c|c|c|c|c|c|c|c|c|c|}
\hline & & $\begin{array}{l}\text { All } \\
(1)\end{array}$ & & $\begin{array}{l}\text { Cross-border } \\
\text { (2) }\end{array}$ & & $\begin{array}{l}\text { Domestic } \\
\text { (3) }\end{array}$ & & $\begin{array}{l}\text { Difference } \\
(2)-(3)\end{array}$ & \\
\hline \multirow[t]{3}{*}{$(-1,1)$} & Mean & $-0.55 * *$ & {$[-2.53]$} & 0.82 * & [1.76] & $-0.51 * * *$ & {$[-2.99]$} & 1.34 ** & {$[2.17]$} \\
\hline & Median & $-0.29 * * *$ & {$[-2.64]$} & 0.43 & [1.52] & $-0.31 * * *$ & {$[-3.13]$} & 0.74 ** & [2.10] \\
\hline & Observations & 427 & & 32 & & 395 & & & \\
\hline
\end{tabular}

B. India

\begin{tabular}{|c|c|c|c|c|c|c|c|c|c|}
\hline & & $\begin{array}{l}\text { All } \\
(1)\end{array}$ & & $\begin{array}{l}\text { Cross-border } \\
\text { (2) }\end{array}$ & & $\begin{array}{l}\text { Domestic } \\
\text { (3) }\end{array}$ & & $\begin{array}{l}\text { Difference } \\
(2)-(3)\end{array}$ & \\
\hline \multirow[t]{3}{*}{$(-1,1)$} & Mean & $48.81 * * *$ & [4.89] & 48.56 *** & [2.96] & $48.98 * * *$ & [3.88] & -0.42 & [0.28] \\
\hline & Median & $15.29 * * *$ & [5.55] & $25.57 * * *$ & [3.50] & $10.94 * * *$ & [4.27] & 14.63 & [0.95] \\
\hline & Observations & 118 & & 47 & & 71 & & & \\
\hline
\end{tabular}

Notes:

1. The parameters for the market model are estimated over the $(-256,-6)$ interval. All targets are publicly traded listed on the domestic/foreign stock exchange.

2. ${ }^{* * *}$ denotes significance at 1 percent level, ${ }^{* *}$ denotes significance at 5 percent level and ${ }^{* * *}$ denotes significance at 10 percent level.

\section{APPENDIX 2. Descriptive Statistics of Empirical Studies of Characteristics of Targets}

The table below provides the descriptive statistics of the variables in Table 3 of this paper. SHR is the announced targeted stock holding ratio by acquirer, SIZE is the natural logarithm of total assets, DER is the total liability divided by market valued capital, CASH is cash reserves divided by total assets, FIXED is fixed assets divided by total assets, ROA is return on assets, MBR is book value of total liability plus market valued capital divided by book value of total assets. Sample period of the data is 1999-2006 for dependent variable and 1998-2005 for the independent variables. The latter is a three-year average. Non-targeted firms by domestic acquirers and foreign acquirers are partly overwrapped, while targeted firms by domestic acquirers and foreign acquirers are not. Overwrapped targeted firms are excluded from the sample. Panel tobit estimation is employed to estimate our empirical equation model. Other than the below variables, three kinds of dummy variables are added. Namely, industrial dummies, year dummies and regional dummies. 
A. China

\begin{tabular}{|c|c|c|c|c|c|c|c|c|}
\hline & & SHR & SIZE & DER & CASH & FIXED & ROA & MBR \\
\hline \multirow{4}{*}{$\begin{array}{l}\text { 1. Firms not Targeted by } \\
\text { Domestic Acquirer } \\
(\mathrm{N}=947)\end{array}$} & Mean & 0.000 & 6.426 & 0.511 & 0.476 & 0.677 & 0.064 & 2.303 \\
\hline & S.D. & 0.000 & 1.242 & 0.524 & 0.181 & 0.221 & 0.087 & 1.344 \\
\hline & Max & 0.000 & 11.560 & 9.961 & 0.961 & 1.000 & 0.431 & 20.456 \\
\hline & Min & 0.000 & 0.354 & 0.005 & 0.012 & 0.048 & -1.338 & 0.738 \\
\hline \multirow{4}{*}{$\begin{array}{l}\text { 2. Firms Targeted by } \\
\text { Domestic Acquirer } \\
(\mathrm{N}=261)\end{array}$} & Mean & 0.282 & 6.151 & 0.842 & 0.506 & 0.665 & 0.048 & 1.437 \\
\hline & S.D. & 0.155 & 1.593 & 0.458 & 0.200 & 0.247 & 0.063 & 0.337 \\
\hline & Max & 1.000 & 9.162 & 2.031 & 0.851 & 0.989 & 0.192 & 2.455 \\
\hline & Min & 0.110 & 1.073 & 0.075 & 0.107 & 0.143 & -0.125 & 1.050 \\
\hline \multirow{4}{*}{$\begin{array}{l}\text { 3. Firms not Targeted by } \\
\text { Foreign Acquirer } \\
(\mathrm{N}=944)\end{array}$} & Mean & 0.000 & 6.425 & 0.512 & 0.477 & 0.677 & 0.064 & 2.299 \\
\hline & S.D. & 0.000 & 1.244 & 0.524 & 0.182 & 0.221 & 0.087 & 1.343 \\
\hline & Max & 0.000 & 11.560 & 9.961 & 0.961 & 1.000 & 0.431 & 20.456 \\
\hline & Min & 0.000 & 0.354 & 0.005 & 0.012 & 0.048 & -1.338 & 0.738 \\
\hline \multirow{4}{*}{$\begin{array}{l}\text { 4. Firms Targeted by } \\
\text { Foreign Acquirer } \\
(\mathrm{N}=34)\end{array}$} & Mean & 0.309 & 6.478 & 0.571 & 0.522 & 0.500 & 0.069 & 1.795 \\
\hline & S.D. & 0.240 & 2.456 & 0.087 & 0.289 & 0.220 & 0.073 & 0.097 \\
\hline & $\operatorname{Max}$ & 1.000 & 8.214 & 0.632 & 0.726 & 0.972 & 0.120 & 1.864 \\
\hline & Min & 0.125 & 4.741 & 0.509 & 0.318 & 0.122 & 0.017 & 1.727 \\
\hline \multirow{4}{*}{$\begin{array}{l}\text { Total } \\
(\mathrm{N}=1,239)\end{array}$} & Mean & 0.283 & 6.425 & 0.512 & 0.477 & 0.677 & 0.064 & 2.299 \\
\hline & S.D. & 0.161 & 1.244 & 0.524 & 0.181 & 0.221 & 0.087 & 1.343 \\
\hline & $\operatorname{Max}$ & 1.000 & 11.560 & 9.961 & 0.961 & 1.000 & 0.431 & 20.456 \\
\hline & Min & 0.110 & 0.354 & 0.005 & 0.012 & 0.048 & -1.338 & 0.738 \\
\hline
\end{tabular}

B. India

\begin{tabular}{|c|c|c|c|c|c|c|c|c|}
\hline & & SHR & SIZE & DER & CASH & FIXED & ROA & MBR \\
\hline \multirow{4}{*}{$\begin{array}{l}\text { 1. Firms not Targeted by } \\
\text { Domestic Acquirer } \\
(\mathrm{N}=764)\end{array}$} & Mean & 0.000 & 7.897 & 3.770 & 0.482 & 0.626 & 0.113 & 1.543 \\
\hline & S.D. & 0.000 & 1.547 & 8.965 & 0.203 & 0.236 & 0.115 & 1.466 \\
\hline & Max & 0.000 & 14.237 & 127.438 & 0.996 & 1.000 & 0.826 & 19.953 \\
\hline & Min & 0.000 & 0.030 & 0.002 & 0.000 & 0.006 & -1.672 & 0.088 \\
\hline \multirow{4}{*}{$\begin{array}{l}\text { 2. Firms Targeted by } \\
\text { Domestic Acquirer } \\
(\mathrm{N}=160)\end{array}$} & Mean & 0.716 & 8.371 & 1.961 & 0.497 & 0.581 & 0.134 & 1.335 \\
\hline & S.D. & 0.336 & 1.816 & 3.210 & 0.211 & 0.229 & 0.231 & 0.640 \\
\hline & Max & 1.000 & 12.218 & 18.970 & 0.914 & 0.998 & 1.598 & 3.390 \\
\hline & Min & 0.100 & 4.762 & 0.031 & 0.062 & 0.101 & -0.123 & 0.563 \\
\hline \multirow{4}{*}{$\begin{array}{l}\text { 3. Firms not Targeted by } \\
\text { Foreign Acquirer } \\
(\mathrm{N}=764)\end{array}$} & Mean & 0.000 & 7.899 & 3.774 & 0.483 & 0.626 & 0.113 & 1.537 \\
\hline & S.D. & 0.000 & 1.556 & 8.970 & 0.203 & 0.236 & 0.117 & 14.464 \\
\hline & $\operatorname{Max}$ & 0.000 & 14.237 & 127.438 & 0.996 & 1.000 & 1.598 & 19.953 \\
\hline & Min & 0.000 & 0.030 & 0.002 & 0.000 & 0.006 & -1.672 & 0.088 \\
\hline \multirow{4}{*}{$\begin{array}{l}\text { 4. Firms Targeted by } \\
\text { Foreign Acquirer } \\
(\mathrm{N}=97)\end{array}$} & Mean & 0.604 & 8.107 & 1.808 & 0.415 & 0.585 & 0.131 & 1.788 \\
\hline & S.D. & 0.342 & 1.015 & 3.074 & 0.214 & 0.210 & 0.080 & 1.091 \\
\hline & Max & 1.000 & 9.757 & 13.921 & 0.824 & 0.930 & 0.319 & 5.891 \\
\hline & Min & 0.100 & 4.922 & 0.032 & 0.067 & 0.275 & -0.046 & 0.541 \\
\hline \multirow{4}{*}{$\begin{array}{l}\text { Total } \\
(\mathrm{N}=1,021)\end{array}$} & Mean & 0.673 & 7.902 & 3.751 & 0.483 & 0.626 & 0.113 & 1.540 \\
\hline & S.D. & 0.343 & 1.551 & 8.926 & 0.203 & 0.236 & 0.116 & 1.460 \\
\hline & $\operatorname{Max}$ & 1.000 & 14.237 & 127.438 & 0.996 & 1.000 & 1.598 & 19.953 \\
\hline & Min & 0.100 & 0.030 & 0.002 & 0.000 & 0.006 & -1.672 & 0.088 \\
\hline
\end{tabular}

APPENDIX 3. Descriptive Statistics of Empirical Studies of Determinants of Cumulative Abnormal Return

The table below provides the descriptive statistics of variables in Table 5 of this paper. CAR_A and CAR_T are the acquirer's and target's three-day cumulative abnormal return. RSIZE is natural logarithm of total assets of acquirer divided by that of target in terms of US dollar, MBR_A and MBR_T are book value of total liability plus market value of capital divided by total assets for acquirer and target, respectively. CASH_T is cash reserve divided by total assets of target. Ownership is targeted stock holding ratio of target announced by acquirer. Sample period of the data is 2000-2005 for both dependent and independent variables. Non-targeted firms are defined as firms that belong to the same industrial category 
of table 2 as targets on every deal, but not targeted. Tobit estimation model is employed to estimate our empirical model. The dataset of this empirical study is not cross-sectional panel data, but cross-sectional data. However, we added year dummy variables since each deals is made in different year. Both $(-1,1)$ window data is used for CAR_A and CAR_T, while we estimated both $(-1,1)$ and $(-20,20)$ in our study. The latter is calculated to reconfirm the result of the former. We extracted deal data for more than 10 percent targeted stock holding ratio when it is announced, but the average of "ownership" is less than 10 percent in the below table because the dataset contains potential targeted firm data that belongs to the same industrial categories of the target, but not targeted. In this case, ownership ratio is " 0 ", so that, the average is less than what was defined.

\section{A. China}

\begin{tabular}{|c|c|c|c|c|c|c|c|c|}
\hline & & CAR_A & CAR_T & RSIZE & MBR_A & MBR_T & Cash_T & Ownership \\
\hline \multirow{4}{*}{$\begin{array}{l}\text { 1. Deals not Targeted by } \\
\text { Foreign Acquirer } \\
(\mathrm{N}=146)\end{array}$} & Mean & 0.000 & 0.000 & 221.035 & 1.347 & 2.124 & 0.068 & 0.000 \\
\hline & S.D. & 0.000 & 0.000 & 266.745 & 0.436 & 1.303 & 0.045 & 0.000 \\
\hline & Max & 0.000 & 0.000 & 972.200 & 2.368 & 7.942 & 0.197 & 0.000 \\
\hline & Min & 0.000 & 0.000 & 0.100 & 0.000 & 0.659 & 0.000 & 0.000 \\
\hline \multirow{4}{*}{$\begin{array}{l}\text { 2. Deals Targeted by } \\
\text { Foreign Acquirer } \\
(\mathrm{N}=31)\end{array}$} & Mean & 0.030 & 0.068 & 36.052 & 1.404 & 3.185 & 0.081 & 0.352 \\
\hline & S.D. & 0.030 & 0.063 & 71.054 & 0.418 & 4.184 & 0.055 & 0.239 \\
\hline & Max & 0.097 & 0.316 & 341.800 & 2.583 & 19.114 & 0.237 & 1.000 \\
\hline & Min & 0.003 & 0.018 & 0.100 & 0.585 & 0.777 & 0.007 & 0.100 \\
\hline Total & Mean & 0.005 & 0.010 & 187.302 & 1.356 & 2.279 & 0.071 & 0.053 \\
\hline \multirow[t]{3}{*}{$(\mathrm{N}=177)$} & S.D. & 0.016 & 0.034 & 253.239 & 0.433 & 2.040 & 0.047 & 0.156 \\
\hline & $\operatorname{Max}$ & 0.097 & 0.316 & 972.200 & 2.583 & 19.114 & 0.237 & 1.000 \\
\hline & Min & 0.000 & 0.000 & 0.100 & 0.000 & 0.659 & 0.007 & 0.000 \\
\hline
\end{tabular}

B. India

\begin{tabular}{|c|c|c|c|c|c|c|c|c|}
\hline & & CAR_A & CAR_T & RSIZE & MBR_A & MBR_T & Cash_T & Ownership \\
\hline 1. Deals not Targeted by & Mean & 0.000 & 0.000 & 14.652 & 1.711 & 1.746 & 0.035 & 0.000 \\
\hline Foreign Acquirer & S.D. & 0.000 & 0.000 & 207.468 & 1.202 & 1.579 & 0.052 & 0.000 \\
\hline \multirow[t]{2}{*}{$(\mathrm{N}=744)$} & Max & 0.000 & 0.000 & 972.200 & 9.767 & 13.330 & 0.429 & 0.000 \\
\hline & Min & 0.000 & 0.000 & 0.000 & 0.312 & 0.238 & 0.000 & 0.000 \\
\hline 2. Deals Targeted by & Mean & 0.120 & 0.059 & 65.630 & 1.981 & 2.471 & 0.040 & 0.174 \\
\hline Foreign Acquirer & S.D. & 0.160 & 0.063 & 68.472 & 0.964 & 1.364 & 0.053 & 0.199 \\
\hline \multirow[t]{2}{*}{$(\mathrm{N}=32)$} & $\operatorname{Max}$ & 0.515 & 0.316 & 334.000 & 3.660 & 5.891 & 0.267 & 1.000 \\
\hline & Min & 0.003 & 0.003 & 3.000 & 0.881 & 0.928 & 0.002 & 0.000 \\
\hline Total & Mean & 0.005 & 0.002 & 143.614 & 1.722 & 1.775 & 0.035 & 0.007 \\
\hline \multirow[t]{3}{*}{$(\mathrm{N}=776)$} & S.D. & 0.039 & 0.017 & 204.532 & 1.193 & 1.577 & 0.052 & 0.051 \\
\hline & $\operatorname{Max}$ & 0.515 & 0.316 & 972.200 & 9.767 & 13.330 & 0.429 & 1.000 \\
\hline & Min & 0.000 & 0.000 & 0.000 & 0.312 & 0.238 & 0.000 & 0.000 \\
\hline
\end{tabular}

\section{APPENDIX 4. Additional Tests for Characteristics of Targets and Determinants of CARs}

These tables summarize the results of regressions of alternate OLS specifications of equation (3.1), (5.1) and (5.2). "4.1" and "4.2" are controlled for potential violation of statistical assumptions underlying the OLS regressions. ${ }^{*}{ }^{* *}$, and ${ }^{* * *}$ denote statistical significance at the $10 \%, 5 \%$, and $1 \%$ levels, respectively.

\subsection{Robustness Checks of Characteristics of Cross-border M\&A Targets}


(A) Cross-border M\&A in China

\begin{tabular}{|c|c|c|c|c|c|c|c|c|c|c|}
\hline & (1) & & & (2) & & (1) & & (2) & & \\
\hline SIZE & -0.150 & $* * *$ & $(-2.760)$ & $-0.144 * *$ & $(-2.220)$ & 0.001 & (1.180) & 0.001 & & (0.920) \\
\hline DER & -0.001 & & $(-0.240)$ & $-4.0 \mathrm{E}-04$ & $(-0.070)$ & -0.002 & $(-1.170)$ & -0.011 & & $(-0.980)$ \\
\hline CASH & 0.180 & $* *$ & $(2.060)$ & 0.134 * & (1.810) & 0.189 & $(1.930)$ & 0.171 & * & (1.680) \\
\hline $\mathrm{CASH}^{*} \mathrm{CASH}$ & & & & -0.110 & $(-0.760)$ & & & -0.001 & & $(-0.660)$ \\
\hline FIXED & -0.048 & & $(-0.310)$ & -0.017 & $(-0.440)$ & 0.003 & $(0.520)$ & 0.001 & & $(0.490)$ \\
\hline MBR & 0.005 & & $(0.290)$ & 0.004 & $(0.640)$ & -0.004 & $(-0.250)$ & -0.002 & & $(-0.170)$ \\
\hline $\mathrm{MBR}^{\star M B R}$ & & & & -0.001 & $(-0.370)$ & & & -0.002 & & $(-0.390)$ \\
\hline Cash Q & 0.001 & ** & $(2.020)$ & $0.004 * *$ & (1.960) & 0.002 & $(2.430)$ & 0.001 & $* *$ & $(2.090)$ \\
\hline SECTOR_1 & 3.7E-04 & ** & (2.340) & $4.2 \mathrm{E}-04 * *$ & $(2.440)$ & 0.003 & $(0.700)$ & 0.004 & & $(0.930)$ \\
\hline SECTOR_2 & -0.003 & & $(-0.020)$ & -0.003 & $(-0.070)$ & -0.002 & $(-0.390)$ & -0.001 & & $(-0.440)$ \\
\hline SECTOR 3 & 0.006 & $* * *$ & $(3.200)$ & $0.001 * * *$ & $(3.400)$ & 0.002 & $(0.450)$ & 0.007 & & $(0.450)$ \\
\hline SECTOR_4 & 0.001 & & $(0.050)$ & 2.3E-05 & $(0.070)$ & -0.017 & $(-0.160)$ & -0.210 & & $(-0.210)$ \\
\hline SECTOR_5 & $1.0 \mathrm{E}-04$ & & $(0.020)$ & 0.001 & $(0.050)$ & -0.012 & $(-1.000)$ & -0.009 & & $(-0.880)$ \\
\hline SECTOR_6 & 0.001 & & $(0.020)$ & $5.1 \mathrm{E}-06$ & $(0.070)$ & -0.003 & $(-0.480)$ & -0.003 & & $(-0.130)$ \\
\hline Year_1 & 0.001 & & $(0.070)$ & $1.5 \mathrm{E}-05$ & $(0.060)$ & -0.001 & $(-0.280)$ & -0.004 & & $(-0.330)$ \\
\hline Year_2 & 8.7E-05 & & $(0.100)$ & $1.4 \mathrm{E}-04$ & $(0.090)$ & $-7.9 \mathrm{E}-05$ & $(-0.020)$ & $-1.4 \mathrm{E}-04$ & & $(-0.010)$ \\
\hline Year_3 & 5.9E-05 & & $(0.070)$ & $5.1 \mathrm{E}-05$ & $(0.070)$ & $2.0 \mathrm{E}-04$ & $(0.040)$ & $3.4 \mathrm{E}-04$ & & $(0.040)$ \\
\hline Year_4 & 0.004 & & $(0.050)$ & 0.001 & $(0.050)$ & -0.006 & $(-1.130)$ & -0.004 & & $(-1.330)$ \\
\hline Year_5 & 0.002 & & $(0.030)$ & 0.005 & $(0.020)$ & 0.013 & $(2.470)$ & 0.004 & ** & $(2.220)$ \\
\hline Region_1 & $-5.6 \mathrm{E}-05$ & & $(-0.060)$ & -0.002 & $(-0.050)$ & 0.002 & $(0.360)$ & 0.001 & & $(0.110)$ \\
\hline Region_2 & 0.009 & & $(1.290)$ & $2.4 \mathrm{E}-04$ & $(1.240)$ & 0.003 & $(0.660)$ & 0.007 & & $(0.740)$ \\
\hline Region_3 & $-6.3 \mathrm{E}-05$ & & $(-0.070)$ & $-3.5 \mathrm{E}-04$ & $(-0.060)$ & 0.004 & $(0.940)$ & 0.006 & & (0.990) \\
\hline Region_4 & 0.001 & & (1.310) & $1.5 \mathrm{E}-04$ & (1.440) & 0.010 & $(-1.140)$ & 0.008 & & $(-1.130)$ \\
\hline Region_5 & -0.001 & & $(-0.080)$ & -0.001 & $(-0.030)$ & -0.003 & $(-0.400)$ & -0.001 & & $(-0.200)$ \\
\hline Constant & 0.001 & & $(0.370)$ & 0.007 & $(0.031)$ & 0.009 & $(0.830)$ & 0.009 & & $(0.770)$ \\
\hline R-squared & 0.005 & & & 0.003 & & 0.005 & & 0.001 & & \\
\hline Observations & 5,928 & & & 5,928 & & 4,950 & & 4,950 & & \\
\hline
\end{tabular}

\subsection{Robustness Checks of Determinants of Cumulative Abnormal Returns}

\begin{tabular}{|c|c|c|c|c|c|c|c|c|}
\hline \multirow[b]{3}{*}{ RSIZE } & \multicolumn{4}{|c|}{ (A) Cross-border M\&A in China } & \multicolumn{4}{|c|}{ (B) Cross-border M\&A in India } \\
\hline & \multicolumn{2}{|c|}{ (1) Acquirer's CARs } & \multicolumn{2}{|c|}{ (2) Target's CARs } & \multicolumn{2}{|c|}{ (1) Acquirer's CARs } & \multicolumn{2}{|c|}{ (2) Target's CARs } \\
\hline & $-2.3 \mathrm{E}-06$ & $(-0.320)$ & $-6.6 \mathrm{E}-06$ & $(-0.170)$ & 9.3E-09 & $(0.030)$ & $-1.3 \mathrm{E}-08$ & $(0.120)$ \\
\hline MBR_A/MBR_T & 0.010 & $(0.790)$ & 0.001 & $(0.820)$ & 0.001 & $(0.380)$ & 0.026 * & $(1.680)$ \\
\hline MBR_A & 0.003 & $(0.830)$ & 0.002 & $(0.710)$ & 0.001 & $(0.710)$ & $2.8 \mathrm{E}-04$ & $(0.580)$ \\
\hline MBR_A*MBR_A & -0.043 & $(-0.470)$ & -0.033 & $(-0.550)$ & -0.047 & $(-0.170)$ & -0.007 & $(-0.780)$ \\
\hline Cash_T & 0.074 & (1.140) & 0.037 & $(0.470)$ & 0.001 & (1.190) & 8.6E-05 & $(0.240)$ \\
\hline Cash_T*Cash_T & -0.018 & $(-0.740)$ & -0.001 & $(-0.700)$ & -0.007 & $(-0.850)$ & -0.004 & $(-0.340)$ \\
\hline MBR_A*Cash_T & $0.110^{* * *}$ & (3.220) & 0.010 * & $(1.770)$ & 0.019 * & (1.840) & 0.006 * & $(1.670)$ \\
\hline Ownership & 4.7E-04 *** & $(4.440)$ & $0.014^{* * *}$ & $(9.510)$ & $0.001 * * *$ & $(4.240)$ & $0.002 * * *$ & $(16.740)$ \\
\hline Year00 & -0.007 & $(-1.460)$ & $-0.019 *$ & $(-1.970)$ & -0.002 & $(-1.190)$ & $0.005 * *$ & (2.100) \\
\hline Year01 & $-0.009 *$ & $(-1.710)$ & -0.011 & $(-2.040)$ & $-0.007 *$ & $(-1.750)$ & -0.001 & $(-0.770)$ \\
\hline Year02 & $-0.008 *$ & $(-1.650)$ & -0.003 & $(-1.020)$ & -0.006 & $(-1.330)$ & -0.001 & $(-0.280)$ \\
\hline Year03 & 0.006 & $(1.140)$ & -0.001 & $(-0.120)$ & -0.007 & $(-1.500)$ & $-2.4 \mathrm{E}-04$ & $(-0.130)$ \\
\hline Year04 & 0.003 & $(0.900)$ & -0.003 & $(-0.070)$ & -0.007 & $(-1.220)$ & -0.002 & $(-0.220)$ \\
\hline Constant & 0.004 & $(0.930)$ & 4.0E-04 & $(0.060)$ & 0.005 & $(1.330)$ & 0.001 & $(0.690)$ \\
\hline R-squared & 0.217 & & 0.366 & & 0.036 & & 0.271 & \\
\hline Observations & 177 & & 177 & & 798 & & 798 & \\
\hline
\end{tabular}

